\title{
Correlation between Bipolar Affective Disorder and Suicide Reviewing by the Risk Factors: a Systematic Review
}

\section{Abstract}

Background: Because there are several reports associations between affective (AD) and bipolar disorder (BD) and suicide, the research develops a discussion of risk factors that influence the occurrence of suicide attempts in patients with $\mathrm{BD}$.

Objectives: To relate risk factors present in patients with bipolar disorder who committed suicide or some suicide attempt.

Methods: A survey was made in Scopus with the keyword "bipolar" and the terms "suicide" and "attempted"and "risk factors" from Medical Subject Headings (MeSH). We use only Scopus as the data source, and the statistical information available in tables and graphs provided from this source.

Results: Frequently the $A D$ and $B D$ were associated with suicide occurrence in the studies included in this review. They identified the main risk factors for suicide the previous suicide attempt and hopelessness. The main risk factors for nonfatal suicidal behavior included family history of suicide, early onset of bipolar disorder, extent of depressive symptoms, increasing severity of affective episodes, the presence of mixed affective states, rapid cycling, comorbid Axis I disorders, and abuse of alcohol or drugs. The suicide rate in this disorder reaches three times compared with other mental illnesses, and there are several risk factors: 3:1 ratio of suicide in men compared to women, but in females a greater number of attempts are observed. $25 \%$ of persons consume alcohol prior to suicidal attempt. The studies relate these factors and show how they can pose a risk to the carrier of the disorder. There are other risk factor for BD discussed on this review.
Sônia Izabel Romero de Souza', Lucas Fortes Portela Ferreira², Lucas Alves Araújo de Oliveira², Racquel Brito da Silva², Antonio Gilvan Teixeira Júnior², Modesto Leite Rolim-Neto 1,2

1 Postgraduate Program in Health Science. Faculty of Medicine of $A B C$, Santo André, São Paulo, Brazil.

2 Faculty of Medicine, Federal University of Cariri, UFCA, Barbalha, Ceará, Brazil.

\section{Contact information:}

Modesto Leite Rolim Neto.

Đmodestorolim@yahoo.com.br 
Conclusions: It is inferred that the factors related to the risk of suicide in patients with bipolar disorder are important to enable the development of strategies designed to identify a possible suicidal ideation, prevention and control of these deaths. These elements are well characterized and defined in the studies.

\section{Keywords}

Bipolar Disorder, Suicide,

Attempted, Risk Factors.

\section{Introduction}

Bipolar affective disorder (BD) is characterized by episodes of depression and hypomania and / or mania. BD has been responsible for the higher rate of suicidal behavior compared to any other mental disorder [1, 2]. It is a potentially lethal disease with a high risk of suicide completed, which again is associated with a history of suicide attempts [2]. During life, about $61 \%$ of patients with BD experiencing suicidal ideation, $25 \%$ to $56 \%$ will attempt suicide, and between $10 \%$ and $19 \%$ die from suicide2. Several studies suggest that previous suicide attempts of bipolar patients may indicate that they are over than 50\% more likely to complete suicide [2]. A better understanding of the characteristics and risk factors related to suicide attempts is the first step to prevent future attempts and early detection of risk patients [1, 2].

Suicide is a tragic potential outcome for patients with bipolar disorder, and unfortunately, this event is not uncommon. Twenty-five percent to $50 \%$ of all bipolar patients have been found to attempt suicide at leart once in their lifetime, with $11 \%$ to $19 \%$ of bipolar patients eventually dying of suicide and standardized mortality ratio for suicide of 12.3 [3-7].

There is evidence that suicide rates among mood disorder patients are more than 20-fold higher than in the general population and that suicidal behavior is much more lethal in bipolar disorder than in the general population [8].

In a review of 10 published studies which had analyzed over 3000 unipolar, BP-I (Bipolar Pacientes), and BP-II patients separately, the pooled data showed the rate of previous suicide attempts to be highest among BP-II patients, followed by BP-I and unipolar cases; bipolar patients, in general, and BP-II patients, in particular, are overrepresented among bothcommitted and attempted suicides [9].

Bipolar patients may exhibit highly perturbed mixed states, which usually increase the suicide risk, especially if treated only with antidepressants and unprotected by mood stabilizers [8].

Besides the associationwith HCL-BP-II, our study found that a family history of completed suicide and of depressive and bipolar disorders was also linked with suicide attempts. Thisfinding confirms those of other studies [10-15].

Bipolar disorder confers a substantially high risk for completed suicide, among the highest of all psychiatric disorders. Among adults with bipolar disorders, $25 \%$ to $50 \%$ make at least 1 suicide attempt in their life-time, and $8 \%$ to $19 \%$ will die of suicide [16]. This study answers the following research question: what are the main risk factors involved with suicide among people with bipolar disorders.

We therefore performed a systematic review of studies of bipolar patients so that is possible to examine the relationship between demographic, clinical, genetic and psychopathological characteristics of patients and their histories of suicidal ideation and attempts.

\section{Methods}

A qualitative systematic review of articles on suicide risk factors in bipolar affective disorder was perfor- 
med, as well as the condition of quality of life of patients in electronic databases previously chosen.

A literature search was conducted via online SCOPUS databases onOctober 2014 and was limited to articles published from January 1, 2010 to 22 September 2014. The reason for limiting the search to 2010-2014 was that during this period there was an expansion of research on new types of comorbidities that influence the risk of suicide in bipolar disorder, and depressive episodes, obesity to genetic polymorphisms. Therefore, bipolar affective disorder and its association with suicide gained greater relevance in the scientific community.

Initially, the search terms browsed onthe SCOPUS database were:

1 "bipolar" (keyword);

2 "suicide" (Medical Subject Headings [MeSH] term);

3. "attempted" (Medical Subject Headings [MeSH] term); and

4. "risk factors" (Medical Subject Headings [MeSH] term).

The following surveys were conducted: 2 AND 3 AND 4. In addition to the MeSH terms, we chose to add the keyword "bipolar" for the search strategy, because, despite not being included in the MeSH thesaurus dictionary, is often used to describe studies that deal with the theme object of this review. The search strategy and the articles retrievedwere analyzed on two separate occasions to ensure adequate sampling.

The article analysis followed previously determined eligibility criteria. We adopted the following inclusion criteria: (1) references written in English; (2) original articles with online accessible full text available in database SCOPUS or CAPES (Higher Education Co-ordination Agency) Journal Portal (Periodicos.capes.gov.br, 2014), a virtual library linked to Brazil's Ministry of Education and subjected to content subscription which offers free access to articles from SCOPUS in full; (3) Studies pertaining to risk factors for suicide in patients with BD; (4) observa- tional studies (descriptive or analytical, except case reports), experimental or quasi-experimental studies, either prospective or retrospective; (5) articles that included in the title at least one combination of terms described in the search strategy. Exclusion criteria were: (1) studies that did not include the proposed topic; (2) original articles without full text accessible online on the SCOPUS or CAPES database; (3) non-original studies, including reviews, editorials, commentaries, prefaces, brief communications and letters to the editor.

Then each paper was read together, and the data elements then were extracted and entered into a table that includes authors, journal, description of the study sample, and the main results (Table 1). Some studies deal with not only the risk factors associated with bipolar disorder, but also with the risk factors in other psychiatric disorders such as schizophrenia and mood disorder, but as the focus of this study are the risk factors associated with suicide in bipolar disorder, related to psychiatric disorders in general studies, they were not recorded or analyzed for this study.

\section{Results}

The main limitation of the studies are number of participants $[20,22,30,91]$ and the unavailable patients who committed suicide before the present study. [22] Other limitations were lack of data about stressful life events,about substance use/abuse at the time of the hospitalisation; 91 treatment with lithium in course of bipolar disorder; 30 the insufficient number of studies some potentially relevant risk factors for suicidal behavior, such as duration of untreated period and bipolar disorder treatment compliance $[20,28]$ lack of the separate analysis of bipolar subtypes $[15,53,99]$ and the difficult-totreat patients referred to the Bipolar Disorder Program, which may limit the ability to generalise our results to the whole spectrum of bipolar disorder [79]. 
Table 1. Risk factors for suicide in bipolar disorder: studies and main findings.

\begin{tabular}{|c|c|c|c|}
\hline $\begin{array}{l}\text { Authors } \\
\text { and Year }\end{array}$ & Journal & Sample & Main findings \\
\hline $\begin{array}{l}\text { Tidemalm, D., } \\
\text { Haglund, A., } \\
\text { Karanti, A., et al } \\
{[37], 2014}\end{array}$ & PLOS ONE & $\begin{array}{l}\text { This was a cohort study of } 6086 \text { bipolar } \\
\text { patients (60\% women) registered in the } \\
\text { Swedish National Quality Register for } \\
\text { Bipolar Disorder 2004-2011 and followed- } \\
\text { up annually 2005-2012. }\end{array}$ & $\begin{array}{l}\text { Recent affective episodes predicted attempted suicide during follow-up and recent } \\
\text { psychiatric inpatient care Further, those with many lifetime depressive episodes were more } \\
\text { likely to attempt suicide. Comorbid substance use disorder was a predictor in men; many } \\
\text { lifetime mixed episodes, early onset of mental disorder, personality disorder, and social } \\
\text { problems related to the primary group were predictors in women. }\end{array}$ \\
\hline $\begin{array}{l}\text { Ciulla, L., Lopes } \\
\text { Nogueira, E., Da } \\
\text { Silva Filho, et al } \\
\text { [107], } 2014\end{array}$ & $\begin{array}{l}\text { Journal of Affective } \\
\text { Disorders }\end{array}$ & $\begin{array}{l}\text { A cross-sectional study with a random } \\
\text { sample of } 530 \text { individuals aged } 60 \text { years or } \\
\text { more from Family Health Strategy of Porto } \\
\text { Alegre, Brazil. }\end{array}$ & $\begin{array}{l}\text { Suicide risk was found in } 15.7 \% \text { of the sample. Female gender, elderly with no income or } \\
\text { with no paid activity and those who have lost one or more of his sons presented association } \\
\text { with suicide risk. Bipolar disorder shows association with suicide risk for those with or } \\
\text { without current episode. }\end{array}$ \\
\hline $\begin{array}{l}\text { Jiménez, E., Arias, } \\
\text { B., Mitjans, M., et } \\
\text { al [127] } 2013\end{array}$ & $\begin{array}{l}\text { European } \\
\text { Neuropsychophar- } \\
\text { macology }\end{array}$ & $\begin{array}{l}\text { One hundred and ninety-nine unrelated } \\
\text { Caucasian bipolar type I or II outpatients } \\
\text { (102 males and } 97 \text { females). }\end{array}$ & $\begin{array}{l}\text { Single SNP analyses showed that suicide attempters had higher frequencies of AA genotype } \\
\text { of the rs669838-IMPA2 and GG genotype of the rs4853694-INPP1gene compared to } \\
\text { non-attempters. T-allele carriers of the rs1732170-GSK3? gene and A-allele carriers of the } \\
\text { rs11921360-GSK3? gene had a higher risk for attempting suicide. }\end{array}$ \\
\hline $\begin{array}{l}\text { Pawlak, J., } \\
\text { Dmitrzak-Weglarz, } \\
\text { M., Skibińska, M., } \\
\text { et al [30], } 2013\end{array}$ & $\begin{array}{l}\text { General Hospital } \\
\text { Psychiatry }\end{array}$ & $\begin{array}{l}\text { A sample of } 189 \text { patients with diagnosis } \\
\text { of unipolar and bipolar affective disorder } \\
\text { ( } n=101 \text { controls) }\end{array}$ & $\begin{array}{l}\text { Protective role of cooperativeness was discovered. Patients with and without suicide attempt } \\
\text { in lifetime history varied in self-esteem position in Value Survey. }\end{array}$ \\
\hline $\begin{array}{l}\text { Ruengorn C., } \\
\text { Sanichwankul K., } \\
\text { Niwatananun W., } \\
\text { et al [1], } 2012\end{array}$ & $\begin{array}{l}\text { Psychology Research } \\
\text { and Behavior } \\
\text { Manage-ment }\end{array}$ & $\begin{array}{l}489 \text { patients diagnosed with Bipolar } \\
\text { Disorder. }\end{array}$ & $\begin{array}{l}\text { Results from the univariate logistic regression analysis revealed that suicide attempters were } \\
\text { younger, single, did not have children, and had little or very little social support. They reported } \\
\text { experiencing more stressful life events, reported being depressed, had suffered from BD at } \\
\text { an early age, had a family history of suicide, had previously attempted suicide, had previous } \\
\text { suicidal ideation, alcohol use, and were prescribed antipsychotics, antidepressants, anxiolytics, } \\
\text { and mood stabilizers. }\end{array}$ \\
\hline
\end{tabular}




\begin{tabular}{|c|c|c|c|}
\hline $\begin{array}{l}\text { Authors } \\
\text { and Year }\end{array}$ & Journal & Sample & Main findings \\
\hline $\begin{array}{l}\text { Finseth, P.I., } \\
\text { Morken, G., } \\
\text { Andreassen, O.A., } \\
\text { et al [22], } 2012\end{array}$ & Bipolar Disorders & 206 consecutive patients & $\begin{array}{l}\text { The lifetime suicide attempt rate in BD inpatients is high. Risk factors of suicide attempts } \\
\text { were: (i) a predominant depressive course of illness, (ii) comorbid alcohol and substance use } \\
\text { disorders, and (iii) a history of AD- and/or alcohol-induced affective episodes. Risk-reducing } \\
\text { factors were a preponderant manic or psychotic course of the illness. These risk factors may } \\
\text { be signs of a clinical subgroup at risk of suicidal behaviour, and seem to be important for } \\
\text { suicide risk assessment in acutely admitted BD patients. }\end{array}$ \\
\hline $\begin{array}{l}\text { Goldstein, T.R. , } \\
\text { Ha, W., Axelson, } \\
\text { D.A., et al [2], } \\
2012\end{array}$ & $\begin{array}{l}\text { Archives of General } \\
\text { Psychiatry }\end{array}$ & $\begin{array}{l}413 \text { youths (mean [SD] age, } 12.6[3.3] \\
\text { years) who received a diagnosis of bipolar } \\
\text { I disorder }(n=244) \text {, bipolar II disorder } \\
\text { ( } n=28) \text {, or bipolar disorder not otherwise } \\
\text { specified ( } n=141) \text {. }\end{array}$ & $\begin{array}{l}\text { Early-onset bipolar disorder is associated with high rates of suicide attempts. Factors such } \\
\text { as intake depressive severity and family history of depression should be considered in the } \\
\text { assessment of suicide risk among youth with bipolar disorder. Persistent depression, mixed } \\
\text { presentations, and active substance use disorder signal imminent risk for suicidal behavior in } \\
\text { this population. }\end{array}$ \\
\hline $\begin{array}{l}\text { Acosta, F.J., Vega, } \\
\text { D., Torralba, L., et } \\
\text { al [7], } 2012\end{array}$ & $\begin{array}{l}\text { Comprehensive } \\
\text { Psychiatry }\end{array}$ & $\begin{array}{l}102 \text { outpatients with a diagnosis of bipolar } \\
\text { disorder. }\end{array}$ & $\begin{array}{l}\text { Patients with bipolar disorder and suicidal history are characterized by the presence of } \\
\text { hopelessness, which probably confers greater vulnerability for suicidal behavior in the } \\
\text { presence of stress factors. This identification of the risk profile for suicidal behavior in } \\
\text { nonsyndromal bipolar patients adds complementary information to risk factors established } \\
\text { for suicidality during acute phases of the disease, allows for differentiated preventive and } \\
\text { treatment approaches of patients at risk, and suggests psychotherapy as an advisable } \\
\text { intervention in this group of patients. }\end{array}$ \\
\hline $\begin{array}{l}\text { Sequeira, A., } \\
\text { Morgan, L., } \\
\text { Walsh, et al [127], } \\
2012\end{array}$ & PLOS ONE & 6 patients non-suicides, 15 suicides. & $\begin{array}{l}\text { Our results thus suggest that suicide-specific expression changes in mood disorders } \\
\text { involve both glucocorticoids regulated metallothioneins and serotonergic signaling in } \\
\text { different regions of the brain. }\end{array}$ \\
\hline $\begin{array}{l}\text { Pompili, M., } \\
\text { Rihmer, Z., } \\
\text { Akiskal, H., et al } \\
\text { [91], } 2012\end{array}$ & $\begin{array}{l}\text { Comprehensive } \\
\text { Psychiatry }\end{array}$ & Participants were 216 consecutive & $\begin{array}{l}\text { Temperaments are important predictors both of suicide risk and psychopathology and may } \\
\text { be used in clinical practice for better delivery of appropriate care to patients with bipolar } \\
\text { disorders. }\end{array}$ \\
\hline
\end{tabular}




\begin{tabular}{|c|c|c|c|}
\hline $\begin{array}{l}\text { Authors } \\
\text { and Year }\end{array}$ & Journal & Sample & Main findings \\
\hline $\begin{array}{l}\text { Goldstein, T.R., } \\
\text { Ha, W., Axelson, } \\
\text { D.A., et al [2], } \\
2012\end{array}$ & $\begin{array}{l}\text { Archives of General } \\
\text { Psychiatry }\end{array}$ & $\begin{array}{l}413 \text { youths (mean [SD] age, } 12.6[3.3] \\
\text { years) who received a diagnosis of bipolar } \\
\text { I disorder ( } n=244) \text {, bipolar II disorder } \\
\text { ( } n=28) \text {, or bipolar disorder not otherwise } \\
\text { specified ( } n=141) \text {. }\end{array}$ & $\begin{array}{l}\text { Early-onset bipolar disorder is associated with high rates of suicide attempts. Factors such } \\
\text { as intake depressive severity and family history of depression should be considered in the } \\
\text { assessment of suicide risk among youth with bipolar disorder. Persistent depression, mixed } \\
\text { presentations, and active substance use disorder signal imminent risk for suicidal behavior in } \\
\text { this population. }\end{array}$ \\
\hline $\begin{array}{l}\text { Acosta, F.J., Vega, } \\
\text { D., Torralba, L., et } \\
\text { al [7], } 2012\end{array}$ & $\begin{array}{l}\text { Comprehensive } \\
\text { Psychiatry }\end{array}$ & $\begin{array}{l}102 \text { outpatients with a diagnosis of bipolar } \\
\text { disorder. }\end{array}$ & $\begin{array}{l}\text { Patients with bipolar disorder and suicidal history are characterized by the presence of } \\
\text { hopelessness, which probably confers greater vulnerability for suicidal behavior in the } \\
\text { presence of stress factors. This identification of the risk profile for suicidal behavior in } \\
\text { nonsyndromal bipolar patients adds complementary information to risk factors established } \\
\text { for suicidality during acute phases of the disease, allows for differentiated preventive and } \\
\text { treatment approaches of patients at risk, and suggests psychotherapy as an advisable } \\
\text { intervention in this group of patients. }\end{array}$ \\
\hline $\begin{array}{l}\text { Sequeira, A., } \\
\text { Morgan, L., } \\
\text { Walsh, et al [127], } \\
2012\end{array}$ & PLOS ONE & 6 patients non-suicides, 15 suicides. & $\begin{array}{l}\text { Our results thus suggest that suicide-specific expression changes in mood disorders } \\
\text { involve both glucocorticoids regulated metallothioneins and serotonergic signaling in } \\
\text { different regions of the brain. }\end{array}$ \\
\hline $\begin{array}{l}\text { Pompili, M., } \\
\text { Rihmer, Z., } \\
\text { Akiskal, H., et al } \\
\text { [91], } 2012\end{array}$ & $\begin{array}{l}\text { Comprehensive } \\
\text { Psychiatry }\end{array}$ & Participants were 216 consecutive & $\begin{array}{l}\text { Temperaments are important predictors both of suicide risk and psychopathology and may } \\
\text { be used in clinical practice for better delivery of appropriate care to patients with bipolar } \\
\text { disorders. }\end{array}$ \\
\hline $\begin{array}{l}\text { Kamali, M., } \\
\text { Saunders, E.F.H., } \\
\text { Prossin, A.R., et al } \\
\text { [161], } 2012\end{array}$ & $\begin{array}{l}\text { Journal of Affective } \\
\text { Disorders }\end{array}$ & $\begin{array}{l}80 \text { bipolar individuals without a history of } \\
\text { suicide and } 56 \text { bipolar individuals with a } \\
\text { past history of suicide }\end{array}$ & $\begin{array}{l}\text { Bipolar individuals with a past history of suicidal behavior exhibit hyperactivity in the HPA } \\
\text { axis. This biological marker remains significant regardless of demographic factors, mood } \\
\text { state, severity and course of illness. This finding in bipolar disorder is consistent with the } \\
\text { evidence for altered HPA axis functioning in suicide and mood disorders and is associated } \\
\text { with a clinical subgroup of bipolar patients at elevated risk for suicide based on their history, } \\
\text { and in need of further attention and study. }\end{array}$ \\
\hline
\end{tabular}


Oquendo, M.A. Galfalvy, H.C., Currier, D., et al [96], 2011

Bellivier, F., Yon L., Luquiens, $\mathrm{A}$ et al [20], 2011

Cassidy, F [53], 2011

Suicide and LifeThreatening Behavior Psychiatry

\section{Bipolar Disorders}

Sample

Main findings

American Journal of 98 patients with bipolar disorder and past suicide attempts. Evaluation of Medication (EMBLEM) is a two-year, prospective, observational study that enrolled 3.684 adult patients with bipolar disorder and initiated or changed oral treatment for an acute manic/mixed episode. Of those, 2.416 patients were eligible for the two-year follow-up.

The study cohort included 87 males and 70 females.
European Mania in Bipolar Longitudinal
176347 persons born from January 1 , followed from their first contact with secondary mental health services after 15 years of age until death, emigration, disappearance, or the end of 2006

entan

Among men, the absolute risk of suicide (95\% confidence interval [CI]) was highest for bipolar disorder. Among women, the highest risk was found among womenwith schizophrenia (4.91\%; Cl: 4.03\%-5.98\%), followed by bipolar disorder (4.78\%; 3.48\%$6.56 \%)$. This is the first analysis of the absolute risk of suicide in a total national cohort of individuals followed up from the first psychiatric contact, and it represents, to our knowledge, the hitherto largest sample with the longest and most complete follow-up. Our estimates are lower than those most often cited, but they are still substantial and indicate the continuous need for prevention of suicide among people with mental disorders.

There were 45 suicide events in 35 participants, including 18 suicide attempts made by 14 participants, six from the lithium group and eight from the valproate group. Despite the high frequency of suicide events during the study, this randomized controlled trial detected no difference between lithium and valproate in time to suicide attempt or suicide event in a sample of suicide attempters with bipolar disorder. However, smaller clinically significant differences between the two drugs were not ruled out.

Baseline variables independently associated with a history of suicidal behavior. Baseline factors associated with a history of suicidal behavior included female gender, a history of alcohol abuse, a history of substance abuse, young age at first treatment for a mood episode, longer disease duration, greater depressive symptom severity (HAMD-5 total score), current benzodiazepine use, higher overall symptom severity (CGI-BP: mania and overall score), and poor compliance. These factors may be considered as potential characteristics to identify subjects at risk for suicidal behavior throughout the course of bipolar disorder.

Factors that may be predictive of suicidality in an exclusively bipolar population are examined. White race, family suicide history, and history of cocaine abuse were predictive of suicidal histories. Gender, nicotine use, medical comorbidity, and history of alcohol and other drug abuse were not, although a trend was noted for a history of benzodiazepine abuse. 


\section{Authors \\ and Year}

Hantouche, E., Angst, J., Azorin,

J.-M. [15], 2010

Disorders

Nordentoft, M., Mortensen, P.B., Pedersen, C.B. [34], 2011

Source of the Document Archives of General Psychiatry

Journal of Clinical

Neves, F.S., Psychiatry

Malloy-Diniz, L.F Romano-Silva,

M.A., et al [110], 2010

Quarantini,

L.C., Miranda-

Scippa, Â., Nery-

Fernandes, F., et

al [57], 2010

Acta Neuropsy-

chiatrica
Sample

A total of 6510 adults, who had been randomly selected through a one-personper-household method, completed interviews (response rate $81.7 \%$ ). All were interviewed using the K-CIDI and a questionnaire for suicide.

176347 persons born from January 1, 1955, through December 31, 1991, were followed up from their first contact with secondary mental health services after 15 years of age until death, emigration, disappearance, or the end of 2006

1,643 individuals with a DSM-IV lifetime diagnosis of bipolar disorder were identified from 43.093 general-population respondents who were interviewed in the 2001-2002 National Epidemiologic Survey on Alcohol and Related Conditions.

Two hundred fifty-five DSM-IV out-patients with bipolar disorder were consecutively recruited from the Bipolar Disorder Program at Hospital das Clínicas de Porto Alegre and the University Hospital at the Universidade Federal de Santa Maria, Brazil.

\section{Main findings}

Results have revealed that unplanned suicide attempters experience suicidal ideation and precipitants prior to their attempt. Further, attempts were associated with affective and alcohol use disorders. Therefore, in order to reduce the number of suicidal attempts, it may be useful to evaluate suicidal ideation concurrent to the treatment of existing mental disorders.

Among men, the absolute risk of suicide (95\% confidence interval $[\mathrm{CI}]$ ) was highest for bipolar disorder. Among women, the highest risk was found among womenwith schizophrenia (4.91\%; Cl: 4.03\%-5.98\%), followed by bipolar disorder (4.78\%; 3.48\%$6.56 \%$ ). This is the first analysis of the absolute risk of suicide in a total national cohort of individuals followed up from the first psychiatric contact, and it represents, to our knowledge, the hitherto largest sample with the longest and most complete followup. Our estimates are lower than those most often cited, but they are still substantial and indicate the continuous need for prevention of suicide among people with mental disorders.

Suicidal behavior is more likely to occur in bipolar respondents who also suffer from alcoho use disorder. Interventions to reduce suicide risk in bipolar disorder need to address the common and highrisk comorbidity with alcohol use disorders.

Our results emphasise the relevance of obesity as an associated factor of suicide attempts in bipolar disorder. Obesity may be seen as correlate of severity and as such, must be considered in the comprehensive management of bipolar patients. 


\begin{tabular}{|c|c|c|c|}
\hline $\begin{array}{l}\text { Authors } \\
\text { and Year }\end{array}$ & Journal & Sample & Main findings \\
\hline $\begin{array}{l}\text { Gomes, F.A., } \\
\text { Kauer-Sant'Anna, } \\
\text { M., Magalhães, } \\
\text { P.V., et al79, } 2010\end{array}$ & $\begin{array}{l}\text { Journal of Affective } \\
\text { Disorders }\end{array}$ & $\begin{array}{l}211 \text { patients suffering from recurrent } \\
\text { major depressive disorder or BPD, } \\
\text { hospitalized after a suicide attempt (SA), } \\
\text { were interviewed by semi-structured } \\
\text { interview and validated questionnaires } \\
\text { about DSM-IV axis I disorders, SA } \\
\text { characteristics and a wide range of } \\
\text { personality traits relevant to suicidal } \\
\text { vulnerability. }\end{array}$ & $\begin{array}{l}\text { Logistic regression analysis showed that serious SA and family history of suicide are closely } \\
\text { associated with a diagnosis of BPD. The presence of both characteristics increase the } \\
\text { association with BDP. Conversely, when looking for the features associated with a serious } \\
\text { SA, BPD was the only associated diagnosis. Lastly, affect intensity was higher in BPD } \\
\text { samples. Serious suicide attempt and a familial history of completed suicide in patients with } \\
\text { major depression seem to be a clinical marker of bipolarity. Facing suicide attempters with } \\
\text { recurrent depression, clinician should be awareness to these characteristics to detect BPD. }\end{array}$ \\
\hline $\begin{array}{l}\text { Guillaume, S., } \\
\text { Jaussent, I., } \\
\text { Jollant, F., et al,99 } \\
2010\end{array}$ & $\begin{array}{l}\text { Journal of Clinical } \\
\text { Psychiatry }\end{array}$ & $\begin{array}{l}\text { We examined prospective data from } 2 \\
\text { cohorts of individuals from the Systematic } \\
\text { Treatment Enhancement Program for } \\
\text { Bipolar Disorder (STEP-BD) study (1999- } \\
\text { 2005) with bipolar disorder. }\end{array}$ & $\begin{array}{l}\text { Risk for poor medication adherence can be estimated and may be useful in targeting } \\
\text { interventions. }\end{array}$ \\
\hline
\end{tabular}


Another limitation is that although data collection was based on structured interviews by trained clinicians with access to hospital records, the data was based on retrospective information from patients and patients who committed suicide before the present study were not available for analysis. [22] It is possible that there is a larger recall bias in the current study because at the time of inclusion interview the patients were still affected by the current affective episode may cause underestimation of manic or hypomanic episodes. However, we cannot exclude the possibility of induced variability in the data. We have no measure of inter-rater reliability, but we have no indication of any systematic variation in the scorings. [22] Furthermore, it is possible that the time period that we used for prospective analyses may have been either too broad or too narrow to adequately capture factors associated with suicidal behavior. Future studies should also aim to expand on the association bet- ween significant life events and suicidal behavior in this population. In addition, we relied on patient and parent reports of suicidal behavior, and these reports were not corroborated with emergency and/or inpatient service records [22]

Initially, the search strategies resulted in a total of 416 original studies. Then, based on the criteria for eligibility, 378 were excluded and 38 other references were included (Figure 1).

It was noted an improvement in the interest on this matter because of the growing number of publications over the years, whose in 2010, 93 scientific studies were found, going to 85 in 2011, 93 in 2012, reaching 100 in 2013 but declining to 46 by September 2014 (Figure 2).

Among the total of 416 studies available in SCOPUS, 253 were original articles, 106 reviews, 16 editorials, 11 letters, 9 notes, 7 conferences, 7 articles in press, 4 book chapters and 3 short surveys (Figure 3). The original articles represented

Figure 1: Flow chart showing study selection for this review.

\begin{tabular}{|c|c|c|}
\hline \multirow{2}{*}{ 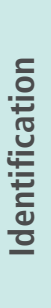 } & $\begin{array}{l}\text { Records identified through } \\
\text { databa se searching } \\
\qquad(n=416)\end{array}$ & $\begin{array}{l}\text { Additional records identified } \\
\text { through other sources } \\
\qquad(\mathrm{n}=0)\end{array}$ \\
\hline & \multicolumn{2}{|c|}{$\begin{array}{l}\text { Records after duplicates removed } \\
\qquad(\mathrm{n}=0)\end{array}$} \\
\hline : & $\begin{array}{l}\text { Records screened } \\
\qquad(n=41)\end{array}$ & $\begin{array}{l}\text { Records excluded } \\
\qquad(n=375)\end{array}$ \\
\hline 흠 & $\begin{array}{l}\text { Full-text articles assessed } \\
\text { for eligibility } \\
\qquad(\mathrm{n}=20)\end{array}$ & $\begin{array}{l}\text { Full-text articles excluded } \\
\text { with reasons } \\
\qquad(\mathrm{n}=21)\end{array}$ \\
\hline $\begin{array}{l}\text { 웡 } \\
\text { 든 }\end{array}$ & \multicolumn{2}{|c|}{$\begin{array}{l}\text { Studies included in qualitative synthesis } \\
\qquad(n=20)\end{array}$} \\
\hline
\end{tabular}


Figure 2: This chart provided by Scopus database was adapted and shows the total of documents for this query Document per year..

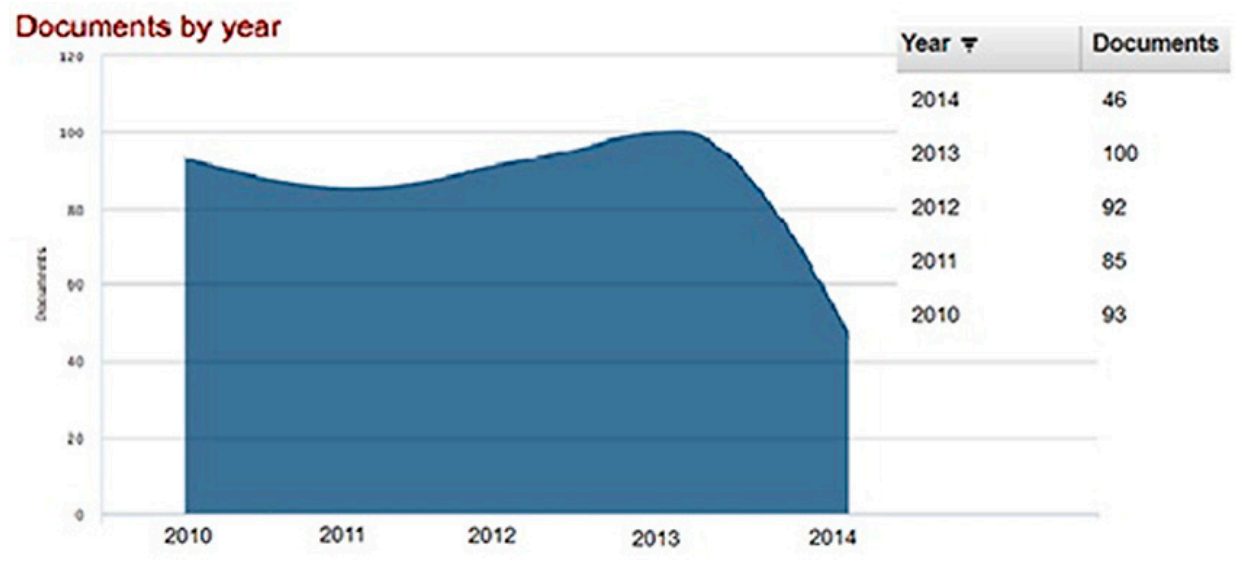

Figure 3: This chart provided by Scopus database shows the total of documents for this query by Document Type.

\section{Documents by type}

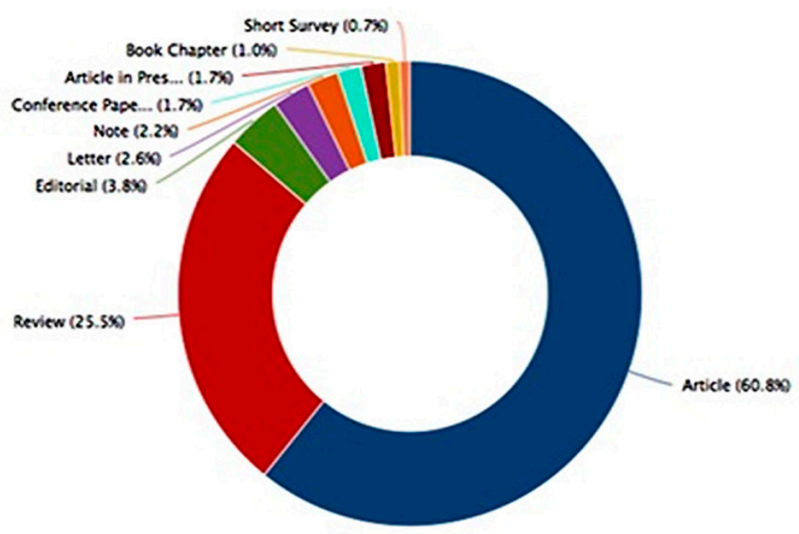

\begin{tabular}{l|l} 
Document Type & Documents \\
\hline Article & 253 \\
Review & 106 \\
Edhorial & 16 \\
Letter & 11 \\
Note & 9 \\
Conference Paper & 7 \\
Article in Press & 7 \\
Book Chapter & 4 \\
Short Survey & 3 \\
Totat & 416
\end{tabular}

$60.8 \%$ results and only 20 (approximately $4.80 \%$ ) are within the criteria elegebilidade and were considered in this review.

The 20 studies were distributed into the previously determined into three categories as follows: Environmental andSocial Criteria (seventeen studies) $[1,2,7,15,20,22,30,34,37,53,57,79,91,96$, 99, 107, 127]; Genetic Criteria (two studies) [110, 127]; BiologicalCriteria (one study) [161]. The categorization of studies aims to a better organizational quality systematic review.

\section{Discussion}

\section{Environmental and Social Criteria}

Bipolar disorder is a prevalent, severe, and disabling disorder often associated with elevated risks of premature mortality, adverse outcomes of comorbid medical disorders, accidents, gender, age, complications of comorbid substance use disorders and enviornmental (Table 2, 3).

Results from the univariate logistic regression analysis revealed that suicide attempters were younger, single, did not have children, and had little or very little social support. They reported 


\section{INTERNATIONAL ARCHIVES OF MEDICINE \\ Section: Psychiatry and Mental Health \\ ISSN: 1755-7682}

Table 2. Sociodemographic factors of patients with BD classified by suicide attempts. This figure was adpted from article 1. Copyright (C) 2012 Ruengorn et al, publisher and licensee Dove Medical Press Ltd.

\begin{tabular}{|c|c|c|c|}
\hline \multirow{3}{*}{$\begin{array}{l}\text { Sociodemographic } \\
\text { factors }\end{array}$} & \multicolumn{2}{|c|}{ Suicide attempts } & \multirow{3}{*}{$P$-evalue } \\
\hline & Yes & No & \\
\hline & $(n=58)$ & $(n=431)$ & \\
\hline \multicolumn{3}{|l|}{ Gender } & \multirow{3}{*}{0.685} \\
\hline Female & $35(60.3)$ & $248(57.5)$ & \\
\hline Male & $23(39.7)$ & $183(42.5)$ & \\
\hline Age (years) & $30.5 \pm 13.6$ & $42.7 \pm 14.6$ & $<0.001$ \\
\hline \multicolumn{3}{|l|}{ Education } & \\
\hline No or primary school & $19(32.6)$ & $180(42.0)$ & \multirow{4}{*}{0.231} \\
\hline Junior to high School & $18(31.0)$ & $131(30.5)$ & \\
\hline Diploma & $9(15.5)$ & $34(7.9)$ & \\
\hline Bachelor or higher & $12(20.7)$ & $84(19.6)$ & \\
\hline \multicolumn{3}{|l|}{ Marital status } & \multirow{4}{*}{0.231} \\
\hline Singler & $32(56.1)$ & 149 (34.9) & \\
\hline Married & $17(29.8)$ & $226(52.9)$ & \\
\hline $\begin{array}{l}\text { Widowed/divorced/ } \\
\text { Other }\end{array}$ & $8(14.1)$ & $52(12.2)$ & \\
\hline \multicolumn{3}{|l|}{ Occupation } & \multirow{5}{*}{0.502} \\
\hline Officer & $13(22.4)$ & $82(19.3)$ & \\
\hline Labor & $24(41.4)$ & $169(39.8)$ & \\
\hline Housewife/student & $4(6.9)$ & $121(28.5)$ & \\
\hline Unemployed & $17(29.3)$ & $53(12.4)$ & \\
\hline \multicolumn{3}{|l|}{ Religion* } & \multirow{3}{*}{0.236} \\
\hline Buddhist & $56(100.0)$ & $411(96.5)$ & \\
\hline Others & $0(0)$ & $13(3.5)$ & \\
\hline \multicolumn{3}{|l|}{ Number of children } & \multirow{4}{*}{0.023} \\
\hline None & $19(63.3)$ & $63(352)$ & \\
\hline $1-2$ & $7(23.3)$ & $83(46.4)$ & \\
\hline$>2$ & $4(13.4)$ & $33(18.4)$ & \\
\hline
\end{tabular}

Living status

\begin{tabular}{|l|c|c|c|}
\hline Alone & $6(11.3)$ & $17(4.2)$ & \\
\hline With family & $42(79.2)$ & $386(92.8)$ & $(0.8)$ \\
\hline With others & $5(9.5)$ & $13(3.0)$ & \\
\hline Social support & & & \\
\hline Good or excellent & $29(56.9)$ & $304(77.0)$ & \\
\hline Moderate & $14(27.4)$ & $69(17.5)$ & 0.001 \\
\hline Very little or litte & $8(15.7)$ & $22(5.5)$ & \\
\hline Stressful life event(s) & & & \\
\hline None & $10(17.2)$ & $165(38.3)$ & 0.003 \\
\hline Yes & $48(82.8)$ & $226(61.7)$ & \\
\hline
\end{tabular}

Notes: Nunbers are $n(\%)$ or mean \pm SD; *Fisher's exact test. Abbreviacions: BD. bipotar disorder. SD. standard deviation
Table 3. Clinical factors of patients with BD classified by suicideattempts. This figure was adpted from article 1. Copyright (C) 2012 Ruengorn et al, publisher and licensece Dove Medical Press Ltd.

\begin{tabular}{|c|c|c|c|}
\hline \multirow{3}{*}{ Clinical factors } & \multicolumn{2}{|c|}{ Suicide attempts } & \multirow{3}{*}{ P-evalue } \\
\hline & Yes & No & \\
\hline & $(n=58)$ & $(n=411)$ & \\
\hline \multicolumn{4}{|l|}{ Mania } \\
\hline No & 11(32.1) & $157(36.4)$ & \multirow{2}{*}{0.628} \\
\hline Yes & $25(67.6)$ & $274(63.6)$ & \\
\hline \multicolumn{4}{|l|}{ Depression } \\
\hline No & $47(81.0)$ & $414(96.1)$ & \multirow{2}{*}{$<0.001$} \\
\hline Yes & $11(19.0)$ & $17(3.9)$ & \\
\hline \multicolumn{4}{|c|}{ Psychotic symptom (s) } \\
\hline No & $54(93.1)$ & $351(81.6)$ & \multirow{2}{*}{0.037} \\
\hline Yes & $4(6.9)$ & 79 (18.4) & \\
\hline \multicolumn{4}{|l|}{ Somatic illness } \\
\hline No & $41(72.4)$ & $287(66.6)$ & \multirow{2}{*}{0.376} \\
\hline Yes & $16(27.6)$ & $144(33.4)$ & \\
\hline \multicolumn{4}{|c|}{ Psychotk comorbidity } \\
\hline No & $43(82.7)$ & $378(90.7)$ & \multirow{3}{*}{0.405} \\
\hline $\begin{array}{l}\text { Alcohol/substance } \\
\text { dependence }\end{array}$ & $8(15.4)$ & $21(5.0)$ & \\
\hline Others & $1(1.9)$ & $18(4.3)$ & \\
\hline \multicolumn{4}{|c|}{ Early age at onset (under 18) } \\
\hline No & $30(54.6)$ & $99(25.2)$ & \multirow{2}{*}{0.004} \\
\hline Yes & $25(45.4)$ & $294(74.8)$ & \\
\hline \multicolumn{4}{|c|}{ Years of BD treatment } \\
\hline$\geq 5$ & $48(85.7)$ & $210(52.8)$ & \multirow{3}{*}{$<0.001$} \\
\hline$>5$ & $6(10.7)$ & $98(24.6)$ & \\
\hline Median (min-max) & $1(1-27)$ & $6(1-40)$ & \\
\hline \multicolumn{4}{|l|}{ Previous admission } \\
\hline No & $23(40.4)$ & $220(51.2)$ & \multirow{2}{*}{0.127} \\
\hline Yes & $34(59.6)$ & $210(48.8)$ & \\
\hline \multicolumn{4}{|c|}{ Mental disorders in famify } \\
\hline No & $37(66.1)$ & $305(77.0)$ & \multirow{2}{*}{0.143} \\
\hline Yes & $13(23.2)$ & $70(17.7)$ & \\
\hline \multicolumn{4}{|l|}{ Suicide in family } \\
\hline No & $49(92.4)$ & $405(99.0)$ & \multirow{2}{*}{0.003} \\
\hline Yes & $4(7.6)$ & $4(1.0)$ & \\
\hline \multicolumn{4}{|c|}{ Number of previous suicide } \\
\hline None & $20(34.5)$ & $348(81.3)$ & \multirow{3}{*}{$<0.001$} \\
\hline $1-2$ times & $20(34.5)$ & $71(16.6)$ & \\
\hline$>2$ times & $18(31.0)$ & $9(2.1)$ & \\
\hline
\end{tabular}




\begin{tabular}{|c|c|c|c|}
\hline \multirow{3}{*}{ Clinical factors } & \multicolumn{2}{|c|}{ Suicide attempts } & \multirow{3}{*}{$P$-evalue } \\
\hline & Yes & No & \\
\hline & $(n=58)$ & $(n=411)$ & \\
\hline \multicolumn{4}{|c|}{ Previous suicidal ideation } \\
\hline No & $17(29.3)$ & $315(73.8)$ & \multirow{2}{*}{$<0.001$} \\
\hline Yes & $41(70.7)$ & $112(26.2)$ & \\
\hline \multicolumn{4}{|l|}{ Smoking } \\
\hline No & $39(71.2)$ & $342(81.4)$ & \multirow{2}{*}{0.112} \\
\hline Yes & $15(27.8)$ & $78(18.6)$ & \\
\hline \multicolumn{4}{|l|}{ Alcohol drinking } \\
\hline No & $35(64.8)$ & $327(77.9)$ & \multirow{2}{*}{0.036} \\
\hline Yes & $19(35.2)$ & $93(22.1)$ & \\
\hline \multicolumn{4}{|l|}{ Any substance abuse } \\
\hline No & $50(92.6)$ & $396(94.5)$ & \multirow{2}{*}{0.569} \\
\hline Yes & $4(7.4)$ & $23(5.5)$ & \\
\hline \multicolumn{4}{|l|}{ Medication adherence } \\
\hline Good & $24(47.1)$ & $288(69.9)$ & \multirow{2}{*}{0.001} \\
\hline Intermittent or poor & $27(52.9)$ & $124(30.1)$ & \\
\hline \multicolumn{4}{|l|}{ Antidepressant } \\
\hline No & $31(53.4)$ & $332(77.0)$ & \multirow{3}{*}{$<0.001$} \\
\hline NE and/or SRI & $2(3.5)$ & $24(5.6)$ & \\
\hline SSRI & $25(431)$ & $75(17.4)$ & \\
\hline \multicolumn{4}{|l|}{ Antipsychotic } \\
\hline No & $8(13.8)$ & $116(26.9)$ & \multirow{4}{*}{0.001} \\
\hline Typical & $23(39.6)$ & $171(39.7)$ & \\
\hline Atypical & $11(19.0)$ & $108(25.1)$ & \\
\hline Both & $16(27.6)$ & $36(8.3)$ & \\
\hline \multicolumn{4}{|l|}{ Anxiolytic } \\
\hline No & $18(31.0)$ & $207(48.0)$ & \multirow{4}{*}{0.041} \\
\hline Benzodiapine & $33(56.9)$ & $173(40.1)$ & \\
\hline Other & $4(6.9)$ & $45(10.4)$ & \\
\hline Both & $3(5.2)$ & $6(1.4)$ & \\
\hline \multicolumn{4}{|l|}{ Mood stabilizer } \\
\hline No & $5(8.6)$ & $87(20.2)$ & \multirow{4}{*}{0.041} \\
\hline Lithium & $25(43.1)$ & $173(40.1)$ & \\
\hline Other & $16(27.6)$ & $138(32.0)$ & \\
\hline Both & $12(20.7)$ & $33(7.7)$ & \\
\hline \multicolumn{4}{|c|}{$\begin{array}{l}\text { Notes: Nunbers are } n(\%) \text { or mean } \pm \text { SD unless other wise } \\
\text { indicated. } \\
\text { Abbreviacions: BD. bipotar disorder. NE: norepinephirene, } \\
\text { SRI: serotonin reuptake inhibitors; } \\
\text { SSRI: selecive serotonin reuptake inhibitors }\end{array}$} \\
\hline
\end{tabular}

experiencing more stressful life events, reported being depressed, had suffered from BD at an early age, had a family history of suicide, had previously attempted suicide, had previous suicidal ideation, alcohol use, and were prescribed antipsychotics, antidepressants, anxiolytics, and mood stabilizers. Meanwhile, psychotic symptoms and increasing years of $\mathrm{BD}$ treatment decreased the probability of suicide attempts.

A suicide attempt (SA) was defined in 1995 by Ayd as any non-fatal, self-inflicted, potentially injurious behavior with any intent to die. This type of behavior encompasses a variety of attitudes, from the simplest acts of self-harm that do not need medical attention, to even more serious actions in which the patient's hospitalization is required $[162,168]$. According to the $\mathrm{WHO}$, in 2002 , suicide attempts (SAs) worldwide accounted for $1.4 \%$ of overall damage caused by all diseases and this rate is estimated to reach $2.4 \%$ in 2020163,168 . In most countries, men display higher rates of completed suicide, but in females a greater number of attempts are observed, probably due to the fact that men generally use more lethal methods and plan the SA with greater determination $[164,168]$. Brazilian studies confirm this trend with a 3:1 ratio of suicide in men compared to women. This ratio is reversed for SAs, with rates three times higher for women than men $[165,168]$. It is estimated that SAs are eight to fifteen times more frequent than suicides [164, 1661, 168]. In Brazil, Botega et al [167], in a study that evaluated, via household survey, 515 randomly selected individuals in the city of Campinas, São Paulo, found prevalence rates of $17.1 \%$ for suicidal ideation, $4.8 \%$ for suicidal plan and $2.8 \%$ for SA $[167,168]$.

Over their lifetime, the vast majority (80\%) of psychiatric patients with bipolar disorders have either suicidal ideation or ideation plus suicide attempts. Depression and hopelessness, comorbidity, and preceding suicidal behavior are key indicators of risk. The prevalence of suicidal behavior in bipolar I and 
II disorders is similar, but the risk factors for it may differ somewhat between the two. [42]

Suicide is most often a complication of psychiatric illness. More than $90 \%$ of suicide victims have a diagnosable psychiatric illness, as well as the vast majority of people who attempt suicide. The pathology most commonly associated with suicide and SAs is severe mood disorder [168, 169, 170]. Goodwin and Jamison [171] reported a prevalence of SA in patients with BD between $20 \%$ and $56 \%$ [168, 171]. The suicide mortality in these patients reaches rates of between $7 \%$ and $19 \%[168,172]$ which comes to fifteen times more than rates found in the general population [168, 173].

Suicide is the leading cause of premature mortality in patients with bipolar disorder [17, 18]. In addition, bipolar disorder is known to be one of the leading mental disorders associated with a high risk of completed suicide and suicidal behaviors [19].

Numerous studies confirm the higher risk of suicidal behaviors in patients with early onset of affective disorder [22, 23, 24, 25]. The risk factors for suicide attempts include history of head injuries [21, $22,26]$, abuse in childhood [21], mania induced by antidepressive treatment [26], more severe course of mania [27], emergence of mixed states and rapid cycling [25], mood instability and coemergence of panic disorder. Many authors point to correlation between suicidal behaviors and abuse of alcohol, other psychoactive substances and drugs [22, 25, 27, 29]. Twenty-five percent of persons consume alcohol prior to suicidal attempt [21]. Leverich et al. also point to family history of abuse of medicinal drugs as a suicide risk factor $[27,30]$.

There is a strong association of drug use with suicidal ideation among girls, and a stronger relationship with attempts among girls and boys. Suicidal youths are ill-adjusted and display a lack of attachment and commitment to family and school. Causal models indicate that poor interpersonal interactions with parents, absence of peer interactions, and life events lead to depression, which in turn leads to sui- cidal ideation. Depressive symptoms are the strongest predictors of suicidal ideation. Among females, depression predicts drug involvement, and in turn, drug use increases suicidal ideation. Drug use is only one class of problem behaviors that constitutes a risk factor for suicidal behavior in adolescence. Delinquency and eating disorders also have direct effects on suicidal ideation beyond those of depressive affect. As for drug involvement, these problem behaviors are more predictive of suicidal behavior among girls than boys. Similarity and specificity of the predictors for problem behaviors within and between the sexes are discussed. Although young women use drugs to handle feelings of depression, drug use appears ineffective in the long run in relieving these depressive feelings. Understanding the dynamics of suicidal ideation in adolescence has important public health implications, since ideation is a strong predictor of attempts, especially among females. [174]

A study has estimated the risk of suicide in bipolar patients to be 20-30 times higher than that of the general population31. The risk is greater among those who have been admitted to inpatient care due to bipolar disorder and especially high in bipolar patients admitted to inpatient care after attempted suicide [32, 33]. Recent studies from Denmark and the UK included bipolar outpatients as well as inpatients. These studies show that the risk of suicide in bipolar disorder, though high, has probably been often overestimated due to a focus on more severely ill, hospital-treated, patients [34, 35]. The Danish study found 5\% suicides among the women and $8 \%$ among the men in those with bipolar disorder in a long-term follow-up of patients after psychiatric contact [34]. The lifetime prevalence of attempted suicide in bipolar patients has been estimated to $34 \%$ in women and $19 \%$ in men [36, 37].

These gender differences in suicidal behaviour may, however, be less pronounced in subjects with bipolar disorder [38]. Also, it has been suggested 
that the risk of suicide is higher in a bipolar type 2 than in type 1 disorder [37, 39, 40].

Suicide attempts were observed in both males and females at similar rates. Moreover, females who attempted suicide were as likely to have attempted suicide by a more violent method as males [175, 181]. Although, it was observed that some authors categorized the female gender as a risk factor [176, 181]. Parmentier et al. (2012) [177, 181] observed that reported rates of suicide attempts among women with bipolar disorders are about twice as high as among men with bipolar disorders, suggesting greater lethality of suicide attempts in men. [177, $178,179,180]$.

Many lifetime mixed episodes, early onset of psychiatric problems, and personality disorder were predictors in women, whereas comorbid substance use disorder was a predictor in men. Further, social problems related to the primary group were a predictor of attempted suicide in women. Contrary to our hypotheses, family history of affective disorder, complicating somatic factors, and violent behaviour did not predict suicide attempt during follow-up [37].

The average global rate of mortality due to suicide is $16 / 100,000$. Statistically speaking, on the global scale, a single suicidal death takes place every $40 \mathrm{~s}$, and an attempt takes place every 3s [41]. About 5\% of the overall population makes at least one suicidal attempt in the entire life cycle [42]. Ninety-five percent patients of emergency rooms after a suicidal attempt were diagnosed with psychiatric disorders, most often depression [43]. It is estimated that $20 \%$ with bipolar affective disorders commit suicide, while 25\%-50\% make suicide attempts [45].

A study proposes a risk-scoring scheme for suicide attempts in Thai patients with BD. This scheme might help health care providers identify patients with BD who are at risk of attempted suicide. First, we explored factors associated with suicide attempts in BD, including gender, younger age at admission,extent of depressive or mi- xed polarity, increasing severity of affective episodes, multiple hospitalizations, comorbid Axis I disorders,abuse of alcohol or illicit drugs, previous suicide attempt(s), previous suicidal ideation, family history of suicide,stressful life events before onset of illness, administration of lithium prophylaxis, and benzodiazepine use [1, 20, 46-52].

With regard to the role of the unipolar - bipolar nature of mood disorders in suicide prediction, a recent review $[9,181]$ of 10 published studies including more than 3000 patients has concluded that bipolar patients, ingeneral, and bipolar II patients, in particular, are over-represented among both committed and attemptedsuicides. Another recent study [42, 181] investigating 90 bipolar I and 101 bipolar II patients also found a (nonsignificant) trend for higher rate of prior suicide attempts at index episode in bipolar II (25\%) than in bipolar I patients (16\%). On the contrary, however, another large-scale, 4044 -year follow-up study $[10,181]$ has found that a higher rate of 186 unipolar (14\%) than the 220 bipolar (I+II) patients (8\%) committed suicide.181

It is estimated that $25 \%$ to $50 \%$ of patients with bipolar disorder will attempt suicide at least once in their lifetime, and that $8 \%$ to $19 \%$ will complete suicide. [182, 184] In general, suicide risk factors can be divided into two groups: distal and proximal factors. The distal factors include the following: family history of suicide, early life adversity, epigenetic factors, personality traits and cognitive style, and chronic substance use. The proximal factors include recent life events, psychopathology, suicidal ideation, and hopelessness. The distal factors increase predisposition, whereas the proximal ones act as precipitants. [183, 184]

The lifetime prevalence of completed and attempted suicides in a large sample of families with bipolar disorder, its relation to family history of major affective disorder and bipolar disorder, and the contribution of clinical and treatment factors to the risk of suicidal behavior was studied in 737 families of probands with major affective disorder 
[184, 185]. Life time psychiatric diagnoses and suicidal behavior in first-degree relatives were assessed. The estimated lifetime prevalence of suicidal behavior (attempted andcompleted suicides) in 737 probands was $38.4+/-3.0 \%$. Lithium treatment decreased suicide risk in probands $(p=0.007)$. In firstdegree relatives, a family history of suicidal behavior contributed significantly to the joint risk of major affective disorder and suicidal behavior $(p=0.0006)$. Thus, the liability to suicidal behavior isinfluenced by genetic factors (particularly family historyof suicidal behavior and major affective disorder. Evenin the presence of high genetic risk for suicidalbehavior, lithium treatmentdecreases suicide rates significantly [184, 185]

An important epidemiological study examined the effect of bipolar disorderand major comorbid disorderson mortality in a population-based longitudinal cohort sample in Taiwan [184, 186]. This study com-pared all-cause and unnatural (suicides and accidents) mortality rates between 1542 subjects with bipolar depression and 17480 patients with other types of depression. The study had three major findings: Bipolar depression was associated with a significantly greater increase in all cause mortality than were other types of depression (hazard ratio 1.3); Patients with bipolar depression faced twice the risk for suicide and approximately twice the risk for accidental death compared with those with other types of depression; Patients with bipolar depression and cardiovascular diseases were 4-times more likely to die from suicide than were those with other types of depressionand cardiovascular diseases [184, 186]. In the authors view, this comorbidity finding is the most important contribution of the study [184].

Comorbid alcohol and drug abuse must be identified and treated since it elevates the risk for suicide $[184,187]$. The same applies to comorbidcardiovascular diseases. Interventions to promote healthy lifestyles and to deliver medical screening andcare may prove valuable for patients with bipolardisorder $[184,186]$
Other factors have been listed as increasing the risk of suicide: previous suicide attempts; history of psychiatric disorders, particularly depression; suicide in family history; history of maltreatment during childhood; hopelessness, tendency to impulsivity or aggression; barriers in access to psychiatric treatment; sense of loss (in personal or social relations, at work, financial loss); somatic disease; easy access to lethal substances; lack of willingness to seek help due to stigmatization associated with emotional problems, abuse of drugs or suicidal thoughts; cultural or religious beliefs, such as belief that suicide is a sublime solution to personal dilemmas; local "epidemics" of suicide; and isolation, sense of loneliness or separation from other people [54, 30, 20].

Patients with bipolar disorder (BD) usually report elevated rates of lifetime posttraumatic stress disorder (PTSD) ranging from $16 \%$ to $39 \%$ of bipolar I patients in the National Comorbidity Survey-Replication. Bipolar women (both I and II) are nearly twice as likely to have PTSD than bipolar men (20.9\% vs. $10.6 \%$ in the STEP-BD study), a finding similar to the ratio found in the general population $[55,56,57]$.

Comorbid posttraumatic stress disorder appears to be an important marker of worse clinical outcomes in BD, including a higher number of suicide attempts, elevated likelihood of rapid cycling, and reduced recovery as evidenced by higher manic symptom scores. Additionally, the presence of PTSD in bipolar patients imposed a lower quality of life status relative to bipolar individuals without PTSD. Thus, PTSD comorbidity must be investigated vigorously in bipolar subjects and should be noted as an increased predictor of suicide risk [57].

The demographic traits include age, gender: male, widow/widower and divorced. As for the social situation, the author lists the following factors: Ioneliness, inability to get help from others, bad financial condition and loss of job or sources of income. The following are of significance in the patient's history and among coexisting disorders: suicide attempts in the past, suicides of close re- 
latives and persons who were important to the patient, the period of bereavement, poor social adaptation, abuse of alcohol, personality disorders (cyclothymic, antisocial), chronic somatic illnesses, chronic insomnia, chronic pain and organic brain disorders (chronic) [58, 59]. The suicide risk factors listed above have been confirmed by other authors $[60,61,62,63,30]$.

Medical comorbidity has been implicated as potential risk factors for suicide attempts or suicide [64]. Family history of suicideis accepted as a risk factor in general, and has been observed in some bipolar cohorts, but not others [53, 65-71].

Family history of completed suicide had the highest odds ratio of significant findings. In previous reports in bipolar cohorts, $[180,188,189]$ family history of suicide was no different between bipolar patients with and without histories of attempts, although one study reported family history was predictive of earlier attempts. [53, 175, 180, 188] Also, the higher frequency of bipolar disorder family history in agitated depression suggests that a bipolar vulnerability may be required to obtain such clustering of hypomanic symptoms. [180, 190] Overall, findings support an association between family functioning and suicidality within families where youths have bipolar disorder. [180, 191] Results suggest that it is plausible that the youth's illness may play an active role in disrupting family processes. Bipolar disorder may involve a potent combination of mood dysregulation and interpersonal processes where threats of harm -against oneself or another- may occur both impulsively and/or instrumentally. [180, 192] No association was found between age and suicide attempts. [180, 193] It is possible that familial depression contributes to offspring suicide risk via multiple avenues, including decreased familial support and increased conflict. [180, 194, 195]

When all significant variables were entered into a multivariate logistic regression, a family history of suicide emerged as the most robust factor explaining suicidal behavior in depression [15].
The studies suggest that cumulative factors act on suicide risk: BP diagnosis, early age of onset, cyclothymic traits, large number of depressive episodes, comorbid alcohol abuse, and suicide in the family. For Slama et al. [11], this clinical configuration could constitute a special BP subgroup at risk of suicidal behavior [15].

Bipolar patients with a history of suicide attempts have been shown to have more markers of severity such as greater suicidal ideation, increased number of hospitalisations, aggressive traits, earlier age at onset, a family history of suicide and of psychiatric and mood disorders, as well as a higher frequency of comorbid anxiety, substance use and cluster B personality disorders [72-76]. One possible link between obesity and suicide in bipolar disorder may be related to depression. Major depression and residual depressive symptoms are the most common phases of bipolar disorder and both are associated with substantial work, social and family functional impairment [77]. Depressive episodes are related to changes in appetite, eating behaviour and physical activity that contribute to obesity $[78,79]$.

In addition to an increased rate of death by suicide, community and clinical studies indicate that bipolar patients usually present a broad range of comorbid general medical conditions, which contribute to overall mortality rates $[80,81]$. Bipolar disorder and comorbid obesity are associated with increased medical morbidity and worse psychiatric outcome [78]. Data from clinical samples have shown that the prevalence of obesity in bipolar disorder patients is exceedingly high, ranging from 20 to $35 \%$, when compared with controls [79, 82-84].

Fagiolini et al. [85] found a positive association between a higher body mass index (BMI) and previous suicide attempts at baseline, in a sample of 175 patients with bipolar I disorder participating in a clinical trial [79].

The obesity was associated with a history of suicide attempts in a sample of outpatients with bipolar disorder, even after controlling for well-established 
risk factors such as lifetime comorbid anxiety and alcohol use disorders and depressive symptoms. Our finding adds to the notion that obesity is a correlate of severity in patients with bipolar disorder, and replicates earlier findings from Fagiolini et al. [79, 85, 86].

Recent data have stressed common features in the underlying pathophysiology of obesity and bipolar disorder which may also be another possible explanation for our findings. Leptin, a key hormone in regulation of adiposity has been shown to be positively associated with risk for depression in a prospective study [87]. Disturbances in metabolic pathways such as insulin-mediated glucose homeostasis, overactivation of the hypothalamic-pituitary-adrenal axis, dysregulated immune and inflammatory processes and adipocytokines profiles are present in both conditions [88]. Such deleterious alterations in key adaptive mechanisms are a component of allostatic load and may explain some of the complex interactions among bipolar disorder, common general medical conditions and resilience to mood episodes and life events $[89,90]$. This framework provides another standpoint from which obesity may be seen as a correlate of allostatic load in bipolar disorder and its relationship with suicide attempts a marker of illness severity [79].

In addition to well-established risk factors such as previous suicide attempts, depressive symptoms and comorbid psychiatric conditions, clinicians must be aware that obesity may be a severity feature relevant not only to pharmacological treatment decisions but also to the comprehensive management of bipolar disorder. It is plausible to speculate that therapeutic interventions targeted to obesity may be of potential benefit in the course of bipolar disorder [79].

Bipolar individuals were more likely to smoke and had elevated BMls com- pared to unaffected controls. Participants who had made a serious suicide attempt or an impulsive less serious attempt with ambivalence or minimal intent were all categorized as attempters. Individuals who had thoughts of suicide but never attemptedalong with those who had never had thoughts of suicide were categorized as non-attempters.

Bipolar individuals who presented with illness duration of less than two years or whose periods of remission were longer than mood episodes were categorized as "not chronic". If they had some form of mood symptom for most of the duration of illness, they were categorized as "chronic". The chronicity status of $6(4.3 \%)$ individuals could not be determined based on the DIGS and records [91].

Overall the bipolar individuals with a history of suicide at- tempt were significantly more likely to be female and non- menopausal, currently smoke cigarettes, have a history of mixed mood episodes or rapid cycling, an elevated BMI and more chronic and persistent course of illness. Bipolar individuals with a history of suicide also had more years of illness and an elevated rate of substance use disorders although the differences did not reach statistical significance [91].

There was no statistical difference in the types of medications used by the two bipolar groups [91]. None was on oral corticosteroids [91].

Results from the univariate logistic regression analysis revealed that suicide attempters were younger, single, did not have children, and had little or very little social support. [1] They reported experiencing more stressful life events, reported being depressed, had suffered from BD at an early age, had a family history of suicide, had previously attempted suicide, had previous suicidal ideation, alcohol use, and were prescribed antipsychotics, antidepressants, anxiolytics, and mood stabilizers. Meanwhile, psychotic symptoms and increasing years of BD treatment decreased the probability of suicide attempts [1].

Depressive episodes, previous suicide attempt(s), stressful life event(s), intermittent or poor medication adherence, and shorter duration of BD treatment (5 years) predicted suicide attempts [1]. Psychotic 
symptom(s) provided an inverse association with suicide risk [1].

Previous suicide attempt(s) emerged as the most robust indicator of attempted suicide in this study, a factor which has also been observed else where. Prior to the current suicide attempt, $65 \%$ of attempters had already attempted suicide, which is also comparable to previous research1. Unlike previous studies, we classified a continuous number of previous suicide attempts into three groups (none, up to 2 times, and more than 2 times) for inclusion in our risk-scoring scheme. Increased odds ratios corresponded with an increased number of previous suicide attempt(s) [1]. This likely reflects more severity, impulsiveness, and risks taken relative to the number(s) of past suicide attempts [1].

Signs and symptoms were also significant1. Patients presenting with depression at the time of visit had almost four times the number of suicide attempts compared to those without depression [1]. Likewise, more frequent suicide attempts during the depressed phase in BD patients have been reported previously. Conversely, psychotic symptoms negatively correlated with suicide attemptsin our riskscoring scheme1. Patients with psychotic symptoms who were impaired in their ability to plan a suicide attempt might explain this result [1].

In this study, we have identified clinical characteristics associated with suicide attempt risk in acutely admitted BD patients using a unique one-site inpatient sample [4]. Among the inpatients with BD-I and BD-II, 45.1\% had attempted suicide at least once [4]. This is within the upper range of previous reports (6), and supports the conclusion that the present study population represents a group of highly affected patients [4]. Leverich et al. (23) reported a rate of $34 \%$ of suicide attempters among their outpatients, using the same definition of a suicide attempt [4].

Many depressive symptoms were associated with suicide attempts [5]. The attempters were more likely than were the nonattempters to have histories of depressive moods or of experiencing loss of interest for at least 1 week [5]. The attempters were also significantly more likely to report histories of major depressive episodes and auditory hallucinations during their most severe depressive episodes5. How- ever, the groups did not differ with respect to histories of elevated moods or manic episodes [5]. The observation that patients with histories of hypomanic episodes were more prevalent in the attempter group seems consistent with the preponderance of those with subtype II of bipolar disorder in this group [5]. The higher incidence of mixed episodes and rapid cycling in the suicide attempters was in accordance with many previous studies [92]. Although the numbers of depressive or manic episodes did not differ between the two groups, the numbers of (hypo) manic episodes and mood episodes were higher in the attempters [5]. The mood episode index, which is the number of episodes divided by the duration of the illness, was also higher in the attempters [5]. The patients with a higher mood episode index may represent not only rapid cyclers but also a more severe subtype of bipolar disorder [5].

Ratings indicate that 58\% attempts were made when subjects reported they were taking pre-scribed psychotropic medication. Subjects reported that, prior to the suicide attempt, they communicated with others regarding their intent to attempt suicide in 69 (42\%) of these attempts. Only $2 \%$ of the attemps were reportedly associated with psychotic symptoms, and 5\% were committed when intoxicated. During follow-up, 31\% of the attemps were preceded by a significant life event per the subject's report; the 2 most commonly reported categories of events included dis- cord in or breakup of a romantic relationship (6\%) and family conflict (5\%) [2].

The substantial risk for suicidal behavior associated with early-onset bipolar disorder: $18 \%$ of youth with bipolar disorder made at least 1 clinically significant suicide attempt within 5 years of study intake, and $8 \%$ made multiple attempts. Attempt rates were 
similar among youth with bipolar I disorder, bipolar II dis- order, and bipolar disorder not otherwise specified [2]. The most potent past and intake factors predictive of a prospectively examined suicide attempt included severity of depressive episode at study intake and family history of depression [2]. More weeks spent with threshold depression, substance use disorder, and mixed mood symptoms, as well as more weeks receiving outpatient psychosocial services in the preceding 8-week period, predicted greater likelihood of a prospective suicide attempt [2]. Therefore, family history, severity of depressive episode at study intake, and near-term persistence of depression, mixed states, and substance use disorder independently contribute to the prediction of prospective suicidal behavior among youth with bipolar disorder at study intake and family history of depression [2].

The stress-diathesis model postulates that suicidal behavior is the result of the interaction between the individual's internal existing threshold of vulnerability (ie, the diathesis) and contemporaneous stress factors. The diathesis, consisting of predisposing factors is trait dependent, includes genetic or familial factorsand may be reflected by a tendency toward pessimism and/or a propensity for aggression and impulsivity [93]. Although hopelessness is regarded to have both trait and state components, the trait component seems to be predominant [94]. Stressors or precipitating factors, on the other hand, are state dependent and include acute aspects of the mood disorder, life events, and/or interpersonal conflicts [93, 95, 96].

The patients in the suicidal ideation group had higher scores in both BDI and BHS scales than those in the suicide attempt group. One possible explanation is that a certain subgroup of patients with suicide attempts may be characterized by greater impulsivity. It has been shown that anxiety and poor impulse control predict which people with suicide ideation act on such thoughts [97]. Patients with bipolar disorder and history of suicide attempts have shown higher levels of impulsivityand aggressivenessthan nonsuicidal patients [96, 98]. However, because we did not assess these features, we were not in a position to test this hypothesis. Nevertheless, future research might do well to consider the possibility of a relationship between Axis II disorders and hopelessness as a trait in patients with bipolar disorder [7].

BPD patients had a greater comorbid lifetime history of substance use (abuse of, or dependence on, drugs and alcohol, excluding tobacco) and a lower comorbid lifetime history of eating disorders. When considering the characteristics of their suicidal history, BPD patients were significantly more likely to have made a serious lifetime SA and to have a family history of completed suicide. The groups did not differ regarding the number of Suicide Attempt (AS) or the age of the first SA or the seriousness of the most recent SA that led to hospitalization. We conversely examined whether a history of both serious SA and family history of completed suicide increased the risk of having a BPD. We found that patients with both characteristics had a higher risk of having a BPD than patients with a family history of completed suicide only or a history ofserious SA only [99].

Initially, we found that a serious SA is strongly associated with BPD. For assessment of suicide attempters, medical lethality and intent to die are two essential concepts $[100,101]$. We found no association between intent to die (measured using the SIS) and any of the mood disorders. These results are consistent with those obtained in a previous study, which found that suicide intent score did not differ between the BPD and MDD groups [99, 102].

Having a BPD diagnosis and male gender increased the risk of higher mortality SA. The potential interaction between gender and type of trial can not be statistically confirmed in any study included in this review.

Tondo et al. [103] found that bipolar patients in general and bipolar II patients in particular, used 
more lethal suicide methods than unipolar ones. Our results, which suggest an association between BPD and serious SA, point in the same direction and could explain, at least inpart, why bipolar patients are relatively over represented among suicide victims with current major depression [99, 104]. Our study found thata high percentage of the elderly with unipolar depression (59.2\%) presented with a suicide risk, as was also the case for those older people with a current and past history of bipolar disorder (62.5\% and 33.3\% respectively). Literature shows that approximately $90 \%$ of people who commit suicide have a diagnosed mental disorder at the moment of death [105].There is a strong relationship between psychiatric diseases and suicide, especially major depression and bipolar depression, which are found in $65-90 \%$ of suicides [106, 107].

This research found a high rate of suicide risk in the elderly population living in the community. The study protocol used prioritized a model able to screen and diagnose mood and cognitive disorders useful and replicable at community and primary care levels108. An Increased mental distress was noted in these evaluated individuals and it was possible to identify some relevant patterns related with suicide risk. Loss of sons may partly explain the suicide risk in some individuals, although the relationship with a subtype of late onset depression and bipolar syndromes deserves further studies. These findings can be a useful to generate other research hypothesis and can beuseful for health professional who care older persons. Detecting characteristics linked to suicide risk, therefore opening up the possibility of preventing self-harmor complete suicide [107].

\section{Genetic Criteria}

Suicide is a complex behavior caused by an interaction of genetic, psychological and social factors $[109,110]$. Genetic variation plays an important role in BD and suicide susceptibility. However, little is known about the genetic influence on the risk of suicide, particularly in BD patients [180, 196].
In BD patients, it has been found an association with impulsivity, impaired decision-making, psychiatric comorbidities, predominance of depressive polarity, delay in performing diagnosis, early illness onset, childhood adversity and a previous suicide attempt [111-118]. It is often hard for clinicians to identify suicidal patients precisely, even knowing well-established risk factors for suicide, because the majority of patients with these characteristics never will kill themselves. However, around one half to two thirds of patients who commit suicide visit physicians less than 1 month before the occurrence, and $10-40 \%$ visit in the preceding week [110, 119, 120].

The identification of biological markers, such as genetic polymorphisms could be useful in helping clinicians prevent suicide behavior. Epidemiological studies have demonstrated that suicidal behavior is, at least partially, genetically determined with a pattern of transmission independent of psychiatric disorders [121]. The level of serotonin activity is influenced by genetic factors, and its association with suicide behavior is strongly established [122]. The serotonin transporter (5-HTT) has a pivotal role in serotoninergic function, because after serotonin is released in the brain synapses, it is taken up into the presynaptic neuron by the 5-HTT, which in turn terminates the synaptic actions of the serotonin and recycles it into the neurotransmitter pool $[110,123]$.

The 5-HTT has a functional polymorphism named 5-HTTLPR which have two alleles: short (S) and long (L). The $S$ allele acts in a nearly dominant way and functionally the uptake of serotonin is approximately 2-fold higher in cells containing the homozygous LL form of the 5-HTTLPR than either the LS or SS forms [124]. It has also been suggested that the $S$ allele of the 5-HTTLPR polymorphism may be associated with suicide behavior, particularly violent suicide attempts, as shown in a recent meta-analysis performed in several psychiatric diagnosis and in a sample composed of only bipolar disorders patients [110, 125-127]. 
The frequency of $S$ allele carriers was higher in those patients who had made a violent suicide attempt in their lifetime in comparison to those who had made a nonviolent suicide attempt. A logistic regression analyses revealed that only the 5-HTTLPR genotype was independently associated with violent suicide attempt [110].

In fact, suicidal behavior, mainly those resulting in death, has a considerable genetic influence. Studies based on epidemiological genetics established that the herdability of suicide is around $45 \%$ and its transmission occurs independently of psychiatric disorders associated [121, 122]. Actually, genotypic distribution was not statistically different between health control group and the BD sample, showing that this polymorphism is not associated with the major phenotype of this illness (mood elevation) [110].

However, it's unclear why the $S$ allele carriers would be disadvantageous to metabolism of serotonin since that reduced serotonin transporter function induced by selective serotonin reuptake inhibitors (SSRIs) improves depression and impulsiveness, two conditions frequently associated with suicidal behavior. Suicidal behavior is considered a complex matter composed by several dimensions or intermediate phenotypes, which the 5-HTTLPR could be different connections. In complex traits, a single gene could be interacting with another genes, environmental factors or psychopathological conditions resulting in multiple effects [110].

No significant differences between the suicide and non-suicide groups were observed for the major demographic variables such as $\mathrm{pH}$, age, RIN, PMI and RNAdeg slope. In order to control for possible confounding effects, demographic variables, such as diagnosis and age, and RNA quality measures (RIN and slope) were used as covariates [128].

A total of 161 genes were found to be differentially expressed in the DLPFC. The most statistically significant gene in this region was the 5-HT2A gene previously identified as being implicated in both mood disorders and in suicide consistently. The decrease of 5-HT2A expression in the suicide group was confirmed by qPCR (data not shown). Enrichment of canonical pathways analysis using Ingenuity confirmed that the serotonin receptor signaling pathway was altered in suicide brain tissue [128]. Another gene of interest previously shown to be involved in suicide [44] and that was altered in the DLPFC was the adenylate cyclase 1 (brain) (ADCY1) gene that codes for a brain specific form of adenylate cyclase responsible of the production of the second messenger cyclic AMP, ADCY was significantly down-regulated in suicide versus non- suicide patients [129]. Finally, period homolog 1 (PER1), a major component of the circadian rhythm system, was also down- regulated in suicides compared to non-suicides [128]. Clock genes have been in the past associated with mood disorders but not specifically with suicide. In summary, the DLPFC data shows it is possible to detect significant expression alterations in human brain areas between suicides and non-suicides brains and confirms the involvement of serotonergic and second messenger system alterations in suicide [130].

A gene expression survey by microarrays in three brain regions (DLPFC, NACC and ACC) revealed alterations in the serotonergic and second messenger systems in the DLPFC and a consistent down-regulation of several members of the metallothionein subfamilies 1 and 2 genes in the NAcc and ACC in mood disorder suicides [127]. Our strategy consisted on using high quality brains (short PMI, high $\mathrm{pH}$, high RIN) with no history of drug dependence, as well as the development of a general linear model in which factors known to influence RNA quality and expression were taken into account when exploring the suicide specific expression changes. This is to our knowledge the first study investigating suicide specific changes in mood disorders in three highly relevant areas as they are involved in the control of impulses and in mood disorders (DLPFC, ACC) and in motivation-reward mechanisms (NAcc). Interestin- 
gly, the most statistically significant gene differentially expressed in suicide victims was the 5-HT2A serotonergic receptor, with a1.28 fold-change reduction in mood disorder subjects that committed suicide versus non-suicide mood disorder subjects. Genetic association studies have often shown that mutations in the 5-HT2A receptor are associated with mood disorders and suicide, as well as with the response to antidepressants [131, 132]. Additionally, gene expression post-mortem studies have revealed alterations 5-HT2Areceptor levels in mood disorder subject suicides when compared to controls. However the direction of the alterations in 5-HT2A is controversial, with some reports showing elevations in the 5-HT2A binding and expression while others showed reduced levels or no differences [133-139]. Recently, a well designed study including matched suicides and controls also confirmed the absence of changes in 5-HT2 binding but reported a decrease in neuronal densities in the prefrontal cortex in a sample of predominantly major depressed suicides140. In another recent study designed to investigate 5-HT2A levels in major depression, Shelton et al. reported an increase in 5-HT2A expression in major depression subjects, but reported no differences when comparing suicides versus non- suicide subjects136. The reduction in 5-HT2A levels is also in concordance with another study comparing suicide versus non-suicide schizophrenia subjects using also Affymetrix microarrays, suggesting that this reduction in 5-HT2A levels might be involved in suicide irrespective of the diagnosis. We also observed decreased expression in suicide group of the brain specific ADCY1, a brain specific form of adenylate cyclase, suggesting altered neurotransmission and cyclic AMP signaling in suicide and confirms previous observations pointing to CAMP signaling alterations in suicide and mood disorders and in animal models of depression [136-145]. Both serotonergic alterations and second messenger systems underline global neurotransmission alterations in the DLPFC that seem to play a role in the predis- position to commit suicide [128]. Beyond thesecriteria, the Brain-derived neurotrophic factor(BDNF) is a member of the large family of neurotrophic fators involved in the development and main tenance of neural cells(Maisonpierreetal.,1991). BDNF is importante in cell survival and apoptosis in neural cells, and it is these factors combined with considerable evidence from human and animal studies that have resulted in the BDNF gene being widely studied in connection with the genética etiology of psychiatric disorders.

Polymorphisms in BDNF have been shown to be associated with bipolar disorder [150] and other conditions such as schizophrenia [151], anxiety [152] and major depression $[153,154]$. Several lines of evidence indicate that BDNF is a good candidate gene for involvement in suicidal behaviour. Post-mortem studies have shown that the expression of BDNF is significantly reduced in individuals that have committed suicide, regardless of psychiatric diagnosis $[155,156]$, and that this reduction is also reflected in the level so fBDNF protein in the hippocampus and pré-frontal cortex [157].

Decreased plasma blood suicide attempts inindividuals with major depressive disorder [158]. BDNF mRNA expression. Is higher in the peripheral blood mononuclear cells of depressed individuals with are cent history of attempted suicide than in depressed individuals with no history of suicide attempt, while both of the segroups have significantly lower BDNF mRNA expression. Than healthy controls [159]. Other genes from the neurotrophin family, nerve growth factor, neurotrophin 3 and neurotrophin 4/5, show decreased levels of mRNA expression. In the brains of suicide completers as compared to control individuals, and this decrease is accompanied by reductions in the irrespective protein levels [160].

\section{Biological Criteria}

There was no statistically significant difference in average awakening cortisol between bipolar or control participants [161]. 
Vol. 8 No. 105 doi: $10.3823 / 1704$
We found elevated bedtime salivary cortisol in bipolar individuals with a history of suicide attempts compared to non- suicidal bipolar individuals. Further supporting our findings, secondary analysis of the intensity of suicidal behavior and level of bedtime cortisol indicated a positive correlation, with the highest cortisol levels reported in individuals that had made a past serious suicide attempt. The difference in bedtime salivary cortisol between suicidal and non-suicidal bipolar individuals remained significant even after controlling for age and sex, BMI, smoking status, childhood sexual abuse, medications, mood state at time of sampling and several clinical factors related to course and severity of illness (substance use disorders, chronicity of illness, rapid cycling) [161].

\section{Conclusion}

Although it is clear that mental disorders in general are associated with suicidal behavior, research has not yet revealed which disorders uniquely predict these outcomes. This is because most studies have examined the associations between individual disorders and suicidal behavior.[197-200]

Althought, in a study with 39685 people (53\% women) admitted to hospital for attempted suicide during 1973-82. A high proportion of suicides in all diagnostic categories took place within the first year of follow-up (14-64\% in men, 14-54\% in women); the highest short term risk was associated with bipolar and unipolar disorder (64\% in men, 42\% in women) and schizophrenia (56\% in men, 54\% in women). The strongest psychiatric predictors of completed suicide throughout the entire follow-up were schizophrenia (adjusted hazard ratio 4.1, 95\% confidence interval 3.5 to 4.8 in men, $3.5,2.8$ to 4.4 in women) and bipolar and unipolar disorder (3.5, 3.0 to 4.2 in men, 2.5, 2.1 to 3.0 in women). Increased risks were also found for other depressive disorder, anxiety disorder, alcohol misuse (women), drug misuse, and personality disorder. The highest population attributable fractions for suicide among people who had previously attempted suicide were found for other depression in women (population attributable fraction 9.3), followed by schizophrenia in men (4.6), and bipolar and unipolar disorder in women and men (4.1 and 4.0, respectively). [33]

Subjects in the ECA data base with a history of bipolar disorder had odds ratios of having had a suicide attempt that were 2.0 and 6.2 times greater than that of persons with unipolar disorder or any other Axis I disorder, respectively. This finding is consistent with the possibility that the rate of suicide among bipolar persons $[36,201]$ is more thant wice as high than that among persons with unipolar disorder [36, 202]. The relatively high rate of suicide attempts among bipolar subjects is not an artifact of age, sex, socioeconomic status, marital status, history of drug and/or alcohol abuse, or comorbidity for panic disorder. [36]

But this higher mortality of bipolar disorde may be caused for several factors that could hypothetically contribute to this phenomenon, such as: an earlier age of onset, greater tendency to psychosis, higher frequency of episodes (including depressive mania), and higher rates of comorbidity for panic disorder [36, 203] and substance abuse [36, 201] may individually or collectively contribute to the higher rate of suicide attempts among persons with bipolar relative to unipolar disorder. [36]

From this review, it can be inferred that Bipolar Disorder has strong relevance to some risk factors for suicide, ranging from substance abuse, and genetic factors to the persistence of depressive episodes. Risk factors for nonfatal suicidal behaviors and for suicide include depression and other mental disorders, alcohol or drug abuse, stressful life events, a family history of suicide, and having a friend or relative commit suicide. These factors are extremely important to do proper monitoring of these patients. [97]

While most research has focused on risk factors forsuicidal behaviour, relatively little attention has 
beengiven to protective factors. [184, 204] Social supports such as family cohesion or a social peer groupas well as marriage and parenthood may reduce the riskof suicide. Cognitive flexibility; active coping strategies and healthy lifestyles are important protective factors. [184, 205] Other potential protective factors include positive and life-affirming beliefs andvalues, high self-esteem and holding attitudes and moralvalues against suicide. This area requires more research [184, 204]

Urges that studies should be done to actually prove the direct interference of factors such as obesity, a cause that by physiological factors and hormonal directly influences the mood of the patient, not to mention the context of prejudice and exclusion because of overweight. In special cases strongly associated with depression, it is important that more concrete relations should be established, so that one can interfere in the treatment of positive way.

In recent years, there has been growing evidence that psychosocial interventions, added to basic pharmacological treatment, can significantly contribute to the stabilization of bipolar disorder. The evidence supports the efficacy of cognitive behavioural therapy (CBT), incombination with pharmacological treatment for the prevention of relapse and of suicidal behavior. [184, 205] Some other psychological treatments are promising: adjunctive CBT [184, 206 , 207] family-focused treatment (FFT) or similar forms of family psychoeducation184,207 interpersonal and social rhythm therapy (IPSRT) and group psychoeducation in preventing depressive and manic recurrences, stabilizing symptoms, or enhancing functioning in 1- to 2-year periods.184

Prevention of suicidal behavior in patients with bipolar disorder should include attention to these risk factors in assessment and treatment, including when deciding whether to initiate treatment aimed specifically at reducing suicide risk [3]

Importantly, nonfatal suicidal behaviors are powerful predictors of subsequent suicide deaths so individuals who talk about killing themselves must always be taken seriously and given as much help as possible by friends, relatives, and mental-health professionals. [97]

Type of psychiatric disorder coexistent with a suicide attempt substantially influences overall risk and temporality for completed suicide. To reduce this risk, high risk patients need aftercare, especially during the first two years after attempted suicide among patients with schizophrenia or bipolar and unipolar disorder. [33]

Therewith, we suggest further studies are needed to identify the characteristics of bipolar and unipolar disorder and other disorders and comorbidity that confer a higher risk for suicide.

\section{Conflict of interest}

The authors have no conflicts of interest or financial ties to report.

\section{Acknowledgments}

We are grateful to the Suicidology Research group - Federal University of Ceará(UFC) / National Council for Scientific and Technological Development (CNPq). Wewould also like to the Scientific Writing Lab (LABESCI) - Federal University of Cariri (UFCA). 


\section{References}

1. Ruengorn, C., Sanichwankul, K., Niwatananun, W., Suwat, M., Wanida, P., Patumanond, J. A risk-scoring scheme for suicide attempts among patients with bipolar disorder in a Thai patient cohort. Psychol Res Behav Manag.2012; 5: 37-45.

2. Goldstein, T.R., Ha, W., Axelson, D.A., Goldstein, B.I., Liao, F., Gill, M.K., Ryan, N.D., Yen, S., Hunt, J., Hower, H., Keller, M., Strober, M., Birmaher, B. Predictors of prospectively examined suicide attempts among youth with bipolar disorder. Arch Gen Psychiatry. 2012; 69 (11): 1113-1122.

3. Hawton K, Sutton L, Haw C, Sinclair J, Harriss L. Suicide and attempted suicide in bipolar disorder: a systematic review of risk factors. J Clin Psychiatry. 2005; 66(6): 693-704.

4. Jamison KR. Suicide and bipolar disorder. J Clin Psychiatry. 2000; 61(Suppl 9): 47-51.

5. Angst J, Angst F, Gerber-Werder R, Gamma A. Suicide in 406 mood- disorder patients with and without long-term medication: a 40 to 44 years' follow-up. Arch Suicide Res. 2005; 9(3): 279-300

6. Angst F, Stassen HH, Clayton PJ, Angst J. Mortality of patients with mood disorders: follow-up over 34-38 years. J Affect Disord. 2002; 68(2-3): 167-81

7. Acosta, F.J., Vega, D., Torralba, L., Navarro, S., Ramallo-Fariña, Y., Fiuza, D., Hernández, J.L., Siris, S.G. Hopelessness and suicidal risk in bipolar disorder: A study in clinically nonsyndromal patients. Comprehensive Psychiatry. 2012; 53 (8), pp. 1103-1109.

8. Pompili, M., Rihmer, Z., Innamorati, M., Lester, D., Girardi, P., Tatarelli, R. Assessment and treatment of suicide risk in bipolar disorders. Expert Rev. Neurother. 2009; 9, 109-136.

9. Rihmer, Z. Prediction and prevention of suicide in bipolar disorders. Clin. Neuropsychiatry.2005; 2: 48-54.

10. Angst, J., Angst, F., Gerber-Werder, R., Gamma, A. Suicide in 406 mood-disorder patients with and without medication: a 40-44 years follow-up. Arch. Suicide Res. 2005b; 9, 279-300.

11. Slama, F., Bellivier, F., Henry, C., et al. Bipolar patients with suicidal behaviour: toward the identification of a clinical subgroup. J. Clin. Psychiatry.2004; 65: 1035-1039

12. Roy, A., Janal, M. Family history of suicide, female sex, and childhood trauma: separate or interacting risk factors for attempts at suicide? ActaPsychiatr. Scand. 2005; 112: 367-371.

13. Hawton, K., Sutton, L., Haw, C., et al. Suicide and attempted suicide in bipolar disorder: a systematic review of risk factors. J. Clin. Psychiatry. 2005; 66,693-704.

14. Borges, G., Angst, J., Nock M.K., Ruscio A.M., Walters E.E., Kessler R.C. A risk index for 12-month suicide attempts in the National Comorbidity Survey Replication (NCS-R). Psychol. Med. 2006; 36: 1747-1757

15. Hantouche, E., Angst J., Azorin J.M., Explained factors of suicide attempts in major depression.J Affect Disord.2010; 127(1-3): 305-308.
16. Goodwin,FK,Jamison, KR. Manic- Depressivelllness: Bipolar Disordersand Re- current Depression. New York, NY: Oxford University Press; 2007.

17. Tondo, L., Isacsson, G., Baldessarini, R. Suicidal behavior in bipolar disorder: risk and prevention. CNS Drugs 2003; 17: 491511.

18. Rihmer, Z. Prediction and prevention of suicide in bipolar disorders. Clin Neuropsychiatry.2005; 2: 48-54

19. Baldessarini,RJ., Tondo, L., Davis, P., Pompili, M., Goodwin FK, Hennen J. Decreased risk of suicides and attempts during long-term lithium treatment: a meta-analytic review. Bipolar Disord.2006; 8: 625-639.

20. Bellivier, F., Yon, L., Luquiens, A., Azorin, JM., Bertsch, J., Gerard, S., Reed, C., Lukasiewicz, M. Suicidal attempts in bipolar disorder: results from observational study. Bipolar Disord. 2011; 377-386.

21. Oquendo,MA., et al. Prospective study of clinical predictors of suicidal acts after a major depressive episode in patients with major depressive disorder or bipolar disorder. Am J Psychiatry. 2004; 161(8): 1433-41.

22. Finseth, P.I., Morken, G., Andreassen, O.A., Malt, U.F., Vaaler, A.E. Risk factors related to lifetime suicide attempts in acutely admitted bipolar disorder inpatients. Bipolar Disord.2012; 14 (7), pp. 727-734

23. MacKinnon,DF., et al. Rapid mood switching and suicidality in familial bipolar disorder. Bipolar Disord. 2005; 7(5): 441-8.

24. Tsai,SJ., Hong, CJ., Wang, YC. Tryptophan hydroxylase gene polymorphism (A218C) and suicidal behaviors. Neuroreport. 1999; 10(18): 3773-5.

25. Hawton, K., et al. Suicide and attempted suicide in bipolar disorder: a systematic review of risk factors. J Clin Psychiatry. 2005; 66(6): 693-704.

26. Slama, F., et al. Bipolar patients with suicidal behavior: toward the identification of a clinical subgroup. J Clin Psychiatry. 2004; 65(8): 1035-9

27. Leverich GS, et al. Factors associated with suicide attempts in 648 patients with bipolar disorder in the Stanley Foundation Bipolar Network. J Clin Psychiatry. 2003; 64(5): 506-15.

28. Dutta, R., et al. Suicide and other causes of mortality in bipolar disorder: a longitudinal study. Psychol Med. 2007; 37(6): 83947.

29. Raja, M., Azzoni, A. Suicide attempts: differences between unipolar and bipolar

patients and among groups with different lethality risk. J Affect Disord 2004; 82(3): 437-42.

30. Pawlak, J., Dmitrzak-Węglarz, M., Skibińska, M., Szczepankiewicz, A., Leszczyńska-Rodziewicz, A., Rajewska-Rager, A., Zaremba, D., Czerski, P., Hauser, J. Suicide attempts and clinical risk factors in patients with bipolar and unipolar affective disorders. General Hospital Psychiatry.2013; 427-432. 
31. Pompili, M., Gonda, X., Serafini, G., Innamorati, M., Sher L, et al. Epidemiology of suicide in bipolar disorders: a systematic review of the literature. Bipolar Disord.2013; 15: 457-490.

32. O'sby, U., Brandt, L., Correia, N., Ekbom,A., Spare'n, P. Excess mortality in bipolar and unipolar disorder in Sweden. Arch Gen Psychiatry. 2001; 58: 844-850

33. Tidemalm, D., Langstrom, N., Lichtenstein, P., Runeson, B. Risk of suicide after suicide attempt according to coexisting psychiatric disorder: Swedish cohort study with long term follow-up. BMJ. 2008; 337: a2205.

34. Nordentoft, M., Mortensen,PB., Pedersen., CB. Absolute risk of suicide after first hospital contact in mental disorder. Arch Gen Psychiatry.2011; 68: 1058-1064.

35. Dutta, R., Boydell, J., Kennedy, N., van Os, J., Fearon, P., et al. Suicide and other causes of mortality in bipolar disorder: a longitudinal study. Psychol Med. 2007; 37: 839-847.

36. Chen, YW., Dilsaver, SC. Lifetime rates of suicide attempts among subjects with bipolar and unipolar disorders relative to subjects with other Axis I disorders. Biol Psychiatry. 1996; 39: 896-899.

37. Tidemalm, D., Haglund, A., Karanti, A., Landén, M., Runeson, B. Attempted Suicide in Bipolar Disorder: Risk Factors in a Cohort of 6086 Patients. PLoS ONE. 2014; 9(4): s.p.

38. Hawton, K., Sutton,L., Haw, C., Sinclair, J., Harriss, L. Suicide and attempted suicide in bipolar disorder: a systematic review of risk factors. J Clin Psychiatry.2005; 66: 693-704.

39. Tondo, L., Isacsson, G., Baldessarini, R. Suicidal behaviour in bipolar disorder: risk and prevention. CNS Drugs.2003; 17: 491511

40. Rihmer Z, Kiss K. Bipolar disorders and suicidal behaviour. Bipolar Disord. 2002; 4 (1): 21-25.

41. Baldessarini, RJ.,Pompili, M., Tondo, L.Suicideinbipolardisorder: Risks and management. CNS Spectr. 2006; 11(6): 465-471.

42. Valtonen, H., Suominen, K., Mantere, O., Leppamaki, S., Arvilommi, P., Isometsa, E-T. Suicidal ideation and attempts in bipolar I and II disorders. J Clin Psychiatry. 2005; 66(11): 1456 1462

43. Goodwin,FK., Jamison, KR. Mania-Depressive Illness: Bipolar Disorders andRecurrent Depression, 2nd ed. New York: Oxford University Press; 2007.

44. Harris, EC.,Barraclough B.Suicideasanout come formental disorders: a meta-analysis. Br J Psychiatry. 1997; 170: 205-228.

45. Isometsa, ET., Henriksson, MM., Aro, HM., Lonngvist, JK. Suicide in bipolar disorder in Finland. Am J Psychiatry. 1994; 151(7): 1020-1024.

46. Azorin, JM., Kaladjian, A., Adida, M., et al. Risk factors associated with lifetime suicide attempts in bipolar I patients: findings from a French National Cohort. Compr Psychiatry. 2009; 50(2): 115120.
47. Oquendo,MA., Watemaux, C., Brodsky, B., et al. Suicidal behavior in bipolar mood disorder: clinical characterisics of attempters andnonattempters. J Affect Disord. 2000; 59(2): 107-117.

48. Hawton, K., Sutton, L., Haw, C., Sinclair, J., Harriss, L.Suicide and attempted suicide in bipolar disorder: a systematic review of risk factors. J Clin. Psychiatry. 2005; 66(6): 693-704.

49. Valtonen, HM., Suominen, K., Mantere, O., Leppamaki, S., Arvilommi, P., Isometsa, ET. Prospective study of risk factors for attempted suicide among patients with bipolar disorder. Bipolar Disord. 2006; 8(5 -2): 576-585.

50. Ryu, V., Jon, D.I.,Cho, H.S.,etal. Initial depressive episodes affecttherisk of suicide attempts in Korean patients with bipolar disorder. Yonsei Med J. 2010; 51(5): 641-647.

51. Tondo, L., Baldessarini, R.J. Long-term lithium treatment in the prevention of suicidal behavior in bipolar disorder patients. Epidemiol Psichiatr Soc. 2009; 18(3): 179-183.

52. Pompili, M., Innamorati, M., Raja, M., et al. Suicide risk in depression and bipolar disorder: Do impulsivenessaggressiveness and pharmacotherapy predict suicidal intent? Neuropsychiatr Dis Treat. 2008; 4(1): 247-255.

53. Cassidy, F. Risk Factors of Attempted Suicide in Bipolar Disorder. The Journal of the American Association of Suicidology. 2011; 41(1): 6-11.

54. Angst, J., Angst, F., Gerber-Werder, R., Gamma,A. Suicide in 406 mood-disorder patients with and without long-term medication: a 40 to 44 years-follow-up. Arch Suicide Res. 2005; 9: 279-300.

55. Baldassano, C.F., Marangell, L.B., Gyulai, L., Nassir Ghaemi, S., Joffe, H., Kim, D.R.,Sagduyu, K., Truman, C.J., Wisniewski, S.R., Sachs, G.S., Cohen, L.S. Gender differences in bipolar disorder: retrospective data fromthe first 500STEP-BD participants. Bipolar Disord. 2005; 7, 465-470.

56. Kessler, R.C., Demler, O., Frank, R.G., Olfson, M., Pincus, H.A., Walters, E.E., Wang, P., Wells, K.B., Zaslavsky, A.M. Prevalence and treatment of mental disorders, 1990 to 2003. N. Engl. J. Med. 2005; 352: 2515-2523

57. Quarantini, L.C., Scippa, Â.M., Fernandes, F.N., Nascimento, M.A., Almeida, A.G., Guimarães,J.L., Teles,C.A.S., Netto, L.R., Lira,S.B., Oliveira, I.R., Post, R.M., Kapczinski, F., Koenen, K.C., The impact of comorbid posttraumatic stress disorder on bipolar disorder patients, J Affect Disord, 2010; 123(1-3): 71-76.

58. Zdrowia, S.O., Suicydologiczne, P.T. Preventing suicide a resource for general physicians. WHO: Genebra, 2002.

59. Pużyński S, Zaburzenia afektywne. Depresje - obraz kliniczny, przyczyny, klasyfikacja. Terapia, numer specjalny, 2004.

60. Cheung, YB., et al. Suicidal ideation and suicidal attempts in a population based study of Chinese people: risk attributable to hopelessness, depression, and socialfactors. J Affect Disord. 2006; 90(2-3): 193-9. 
61. Brezo, J., Paris, J., Turecki, G. Personality traits as correlates of suicidal ideation, suicide attempts, and suicide completions: a systematic review. Acta Psychiatr Scand. 2006; 113(3): 180-206.

62. Lewis, G., Sloggett, A. Suicide, deprivation, and unemployment: record linkagestudy. BMJ. 1998; 317(7168): 1283-6.

63. Sher, L. Alcoholism and suicidal behavior: a clinical overview. Acta Psychiatr Scand. 2006; 113(1): 13-22.

64. American Psychiatric Association. Practice guideline for the assessment and treatment of patients with suicidal behaviors. American Journal of Psychiatry .2003; 160 (Suppl. 11), 1-60.

65. Roy, A. Family history of suicide. Arch Gen Psychiatry; 1983; 40: 971-974.

66. Roy, A., Segal, N. L., Centerwall, B. S., \& Robinette, C. D. Suicide in twins. Arch Gen Psychiatry; 1991; 48, 29-32.

67. Leverich, G. S., Altshuler, L. L., Frye, M. A., Suppes, T., Keck, P.E. Jr., Mcelroy, S. L., et al. Factors associated with suicide attempts in 648 patients with bipolar disorder in the Stanley Foundation Bipolar. J Clin Psychiatry.2003; 64(5): 506-15.

68. Lopez, P., Mosquera, F., De Leon, J., Gutierrez, M., Ezcurra, J., Ramirez, F., et al. Suicide attempts in bipolar patients. J Clin Psychiatry.2001; 62: 963-966.

69. Tsai, S.Y., Kuo, C.J., Chen, C. C., Lee, H. C. Risk factors for completed suicide in bipolar disorder. J Clin Psychiatry. 2002; 63: 469-476.

70. Galfalvy., H., Oquendo., M. A., Carballo, J.J., Sher., L., Grunebaum., M. F., Burke, A., et al. Clinical predictors of suicidal acts after major depression in bipolar disorder: A prospective study. Bipolar Disord. 2006; 8(2-5): 586-595.

71. Valtonen, H., M., Suominen, K., Mantere, O., Leppamaki, S., Arvilommi, P., \& Isometsa, E. T. Prospective study of risk factors for attempted suicide among patients with bipolar disorder. Bipolar Disord. 2006; 8(5 -2), 576-585.

72. Grunebaum,MF., Ramsay, SR., Galfalvy, H.C. et al. Correlates of suicide attempt history in bipolar disorder: a stressdiathesis perspective. Bipolar Disord. 2006; 8: 551-557.

73. S'anchez-Gistau, V., Colom, F., Man'e, A., Romero, S., Sugranyes, G., Vieta, E. Atypical depression is associated with suicide attempt in bipolar disorder. Acta Psychiatr Scand. 2009; 120: 30-36.

74. Rosa, AR., Franco, C., Martínez-Aran, A. et al. Functional impairment and previous suicide attempts in bipolar disorder. Acta Neuropsychiatr. 2008; 20: 300-306.

75. Simon, G.E., Hunkeler, E., Fireman, B., Lee, J.Y., Savarino,J. Risk of suicide attempt and suicide death in patients treated for bipolar disorder. Bipolar Disord. 2007; 9: 526-530.

76. Neves, F.S, Malloy-Diniz,L.F., Corrêa H. Suicidal behavior in bipolar disorder: what is the influence of psychiatric comorbidities? J Clin Psychiatry. 2009; 70: 13-18.

77. Post, R.M. The impact of bipolar depression.J Clin Psychiatry. 2005; 66(Suppl. 5): 5-10.
78. Wildes, J.E., Marcus, M.D., Fagiolini, A. Obesity in patients with bipolar disorder: a biopsychosocial-behavioral model. J Clin Psychiatry. 2006; 67: 904-915.

79. Gomes, F. A., Kauer-Sant'Anna, M., Magalhães, P. V., Jacka, F. N., Dodd, S., Gama, C. S., Cunha, Â., Berk, M., Kapczinski, F. Obesity is associated with previous suicide attempts in bipolar disorder. Acta Neuropsychiatr.2010; 22: 63-67.

80. Angst, F., Stassen, H.H., Clayton, P.J., Angst, J. Mortality of patients with mood disorders: follow-up over 34-38 years. J Affect Disord. 2002; 68: 167-181.

81. Roshanaei-Moghaddam, B., Katon, W. Premature mortality from general medical illnesses among persons with bipolar disorder: a review. Psychiatr Serv. 2009; 60: 147-156.

82. Elmslie, J.L., Silverstone, J.T., Mann, J.I., Williams, S.M., Romans, S.E. Prevalence of overweight and obesity in bipolar patients. J Clin Psychiatry 2000; 61: 179-184.

83. McElroy, S.L., Frye, M.A., Suppes, T. et al. Correlates of overweight and obesity in 644 patients with bipolar disorder. J Clin Psychiatry. 2002; 63: 207-213.

84. Fagiolini, A., Kupfer, D.J., Houck, P.R., Novick, D.M., Frank, E. Obesity as a correlate of outcome in patients with bipolar I disorder. Am J Psychiatry. 2003; 160: 112-117.

85. Fagiolini. A., Kupfer, D.J., Rucci, P., Scott, J.A., Novick, D.M., Frank, E. Suicide attempts and ideation in patients with bipolar I disorder. J Clin Psychiatry. 2004; 65: 509-514.

86. Fagiolini, A., Frank, E., Scott, J.A., Turkin, S., Kupfer, D.J. Metabolic syndrome in bipolar disorder: findings from the Bipolar Disorder Center for Pennsylvanians. Bipolar Disord. 2005; 7: 424-430.

87. Pasco, J., Jacka, F., Williams, L.J. et al. Leptin in depressed women: cross-sectional and longitudinal data from an epidemiologic study. J Affect Disord. 2007; 107: 211-225.

88. Mclntyre, R.S., Soczynska, J.K., Konarski, J.Z. et al. Should depressive syndromes be reclassified as "metabolic syndrome type II" ? Ann Clin Psychiatry. 2007; 19: 257-264.

89. McEwen, B.S. Mood disorders and allostatic load. Biol Psychiatry. 2003; 54: 200-207.

90. Kapczinski, F., Vieta, E., Andreazza, A.C. et al. Allostatic load in bipolar disorder: implications for pathophysiology and treatment. Neurosci Biobehav Rev. 2008; 32: 675-692.

91. Pompili, M., Rihmer, Z., Akiskal, H., Amore, M., Gonda, X., Innamorati, M., Lester, D., Perugi, G., Serafini, G., Telesforo, L., Tatarelli, R., Girardi, P. Temperaments mediate suicide risk and psychopathology among patients with bipolar disorders. Comprehensive Psychiatry. 2012; 53 (3): 280-285.

92. Valtonen, H. Suicidal behaviour in bipolar disorder. Helsinki, Finland: National Public Health Institute. 2007.

93. Mann, J.J., Waternaux, C., Haas, G.L., Malone, K.M. Toward a clinical model of suicidal behavior in psychiatric patients. Am J Psychiatry. 1999; 156(2): 181-9. 
94. Young, M.A., Fogg, L.F, Scheftner, W., Fawcett, J., Akiskal, H., Maser, J. Stable trait components of hopelessness: baseline and sensitivity to depression. J Abnorm Psychol. 1996; 105(2): 15565.

95. Oquendo, M.A.,Waternaux, C.,Brodsky, B.,Parsons, B.,Haas, G.L.,Malone K.M., et al. Suicidal behavior in bipolar mood disorder: clinical characteristics of attempters and nonattempters. J Affect Disord. 2000; 59(2): 107-17.

96. Oquendo, M.A., Galfalvy, H., Russo, S., Ellis, S.P., Grunebaum, M.F., Burke, A., et al. Prospective study of clinical predictors of suicidal acts after a major depressive episode in patients with major depressive disorder or bipolar disorder. Am J Psychiatry. 2004; 161(8): 1433-41

97. Nock, M.K., Hwang, I., Sampson, N., Kessler, R.C., Angermeyer, M., Beautrais. A., et al. Cross-national analysis of the associations among mental disorders and suicidal behavior: findings from the WHO World Mental Health Surveys. PLoS Med. 2009; 6(8): e1000123.

98. Grunebaum, M.F., Ramsay, S.R., Galfalvy, H.C., Ellis, S.P., Burke, A.K., Sher, L., et al. Correlates of suicide attempt history in bipolar disorder: a stress-diathesis perspective. Bipolar Disord. 2006; 8(5 -2): 551-7.

99. Guillaume, S., Jaussent, I., Jollant,F., Rihmer, Z., Malafosse,A., Courtet,P., Suicide attempt characteristics may orientate toward a bipolar disorder in attempters with recurrent depression.J Affect Disord. 2010; 122(1-2): 53-59.

100. Haw, C., Hawton, K., Houston, K., Townsend, E. Correlates of relative lethality and suicidal intent among deliberate selfharm patients. Suicide Life Threat Behav.2003; 33: 353-364.

101. Oquendo, M. H. B. M. J. Risk factors of suicidal behavior: the utility andlimitations of research instruments. In: ED, F.M. (Ed.), Standardized Evaluation in Clinical Practice. American Psychiatric Publishing, Washington, DC. 2003.

102. Kumar, C.T., Mohan, R., Ranjith, G., Chandrasekaran, R. Characteristicsof high intent suicide attempters admitted to a general hospital. J Affect Disord.2006; 91: 77-81.

103. Tondo, L., Lepri, B., Baldessarini, R.J. Suicidal risks among 2826 Sardinian major affective disorder patients. Acta Psychiatr Scand. 2007; 116: 419-428.

104. Rihmer, Z. Prediction and prevention of suicide in bipolar disorders. Clin Neuropsychiatry. 2005; 48-54

105. Barrero, S., Matusevich, D., Suicidio en la vejez. Editorial Polemos, Buenos Aires, AR. 2009.

106. Sudbrack,R.W.G.,CataldoNeto, A. Suicídio em idosos.Acta Med. 2009; 31: 648-656.

107. Ciulla, L., Nogueira, E.L., Filho, I.G.S., Tres, G.L., Engroff, P., Ciulla, V., Neto,A.C., Suicide risk in the elderly: Data from Brazilian public health care program, J Affect Disord. 2014; 152-154: 513-516.
108. Nogueira, E.L., Moretti, P.F., Ribeiro Junior, F.J.P., Diefenthaeler, E.C., Cataldo Neto, A., Engroff, P., Borges Filho, J.C., Loureiro, F., Gomes, I. The mental health research protocol of the multidimensional study of the elderly in the family health strategy in Porto Alegre, Brazil (EMI-SUS).Pan American Journal of Aging Research 1. 2013; 1(1): 20-24.

109. Corrêa, H., Campi Azevedo, A.C., De Marco, L., Boson, W., Viana, M.M., Guimarães, M.M., Costa, E., Miranda, D.M., Romano-Silva, M.A. Familial suicide behavior association with probands suicide attempt characteristics and 5-HTTLPR polymorphism. Acta Psychiatr. Scand. 2006; 110: 459-464.

110. Neves, F.S., Diniz,L.F.M, Silva, M.A.R, Aguiar, G.C., Matos,L.O., Correa, $H_{\text {., }}$ Is the serotonin transporter polymorphism (5-HTTLPR) a potential marker for suicidal behavior in bipolar disorder patients?J Affect Disord. 2010: 125(1-3): 98-102.

111. Swann, A.C.,Dougherty,D.M., Pazzaglia, P.J., Pham,M., Steinberg, J.L.,Moeller, F.G. Increased impulsivity associated with severity of suicide attempt history in patients with bipolar disorder. Am. J. Psychiatry. 2005; 162: 1680-1687.

112. Malloy-Diniz, L.F., Neves, F.S., Abrantes, S.S., Fuentes, D., Corrêa, H. Suicide behavior and neuropsychological assessment of type I bipolar patients. J. Affect. Disord.2009; 112: 231-236.

113. Neves, F.S., Malloy-Diniz, L.F., Corrêa, H., Suicidal behavior in bipolardisorder: what is the influence of psychiatric comorbidities? J. Clin. Psychiatry. 2008a; 70: 13-18.

114. Rosa, A.R., Andreazza, A.C., Kunz, M., Gomes, F., Santin, A., Sanchez-Moreno, J., Reinares, M., Colom, F., Vieta, E., Kapczinski, F. Predominant polarity in bipolar disorder: diagnostic implications. J. Affect. Disord.2008; 107: 45-51.

115. Shi, L., Thiebaud, P., McCombs, J.S. The impact of unrecognized bipolar disorders for patients treated for depression with antidepressants in the fee-for-services California Medicaid (Medi-Cal) program. J. Affect. Disord.2004; 82: 373-383.

116. Tondo, L., Lepri, B., Baldessarini, R.J., Suicidal risks among 282 Sardinian major affective disorder patients. Acta Psychiatr. Scand. 2007; 116: 419-428.

117. Brown, G.R., McBride, L., Bauer, M.S., Williford, W.O. Cooperative Studies Program 430 Study Team. Impact of childhood abuse on the course of bipolar disorder: a replication study in U.S. veterans. J. Affect. Disord.2005; 89: 57-67.

118. Oquendo, M.A., Currier, D., Mann, J.J. Prospective studies of suicidal behavior in major depressive and bipolar disorders: what is the evidence for predictive risk factors? Acta Psychiatr. Scand. 2006; 114: 151-158

119. Blumenthal, S.J., Suicide: a guide to risk factors, assessment, and treatment of suicidal patients. Med. Clin. North Am. 1988; 72: 937-971.

120. Robins, E., Murphy, G.E., Wilkinson, R.H., Gassner, S., Kayes, J. Some clinical considerations in the prevention of suicide based on a study of 134 successful suicides. Am. J. Public Health. 1959; 49: 888-899. 
121. Bondy, B., Buettner, A., Zill, P. Genetics of suicide. Mol. Psychiatry. 2006; 11: 336-351.

122. Mann, J.J., Brent, D.A., Arango, V. The neurobiology and genetics of suicide and attempted suicide: a focus on the serotonergic system. Europsychopharmacology.2001; 24: 467477.

123. Ramamoorthy, S., Bauman, A.L.,Moore, K.R., Han, H. Yang-Feng, T., Chang, A.S., Ganapathy, V., Blakely, R.D Antidepressant- and cocaine-sensitive human serotonin transporter: molecular cloning, expression, and chromosomal localization. Proc. Nat. Acad. Sci. 1993; 90: 2542-2546.

124. Lesch, K.P., Bengel, D., Heils, A., Sabol, S.Z., Greenberg, B.D., Perri, S., Benjamin, J., Muller, C.R.,Hamer, D.H.,Murphy, D.L. Association of anxiety-related traits with a polymorphism in the serotonin transporter gene regulatory region. Science.1996; 274: $1527-1530$

125. Li, D., He, L. Meta-analysis supports association between serotonina transporter (5-HTT) and suicidal behavior. Mol. Psychiatry. 2007; 12: 47-54.

126. Neves, F.S., Silveira, G., Romano-Silva, M.A., Malloy-Diniz, L., Ferreira, A.A., De Marco, L., Correa, H. Is the 5-HTTLPR polymorphism associated with bipolar disorder or with suicidal behavior of bipolar disorder patients? Am. J. Med. Genet. B Neuropsychiatr. Genet. 2008b ; 147B: 114-116.

127. Jimenez, E., Arias, B., Mitjans, M., Goikolea, J., Roda, E., Saiz, P., Garcı-Portilla, M., Buron, P., Bobes, J., Oquendo, M., Vieta, E., Benabarre, A. Genetic variabilityat IMPA2,INPP1 and GSK3b increases the risk of suicidal behavior in bipolar patients. European Neuropsychopharmacology.2012. 14521462.

128. Sequeira, A., Morgan, L., Walsh, D.M., Cartagena, P.M., Choudary, P., Li, J., Schatzberg, A.F., Watson, S.J., Akil, H., Myers, R.M., Jones, E.G., Bunney, W.E., Vawter, M.P. Gene expression changes in the prefrontal cortex, anterior cingulate cortex and nucleus accumbens of mood disorders subjects that committed suicide. PLoS ONE. 2012; 7 (4): e35367,

129. Garbett, K., Gal-Chis, R., Gaszner, G., Lewis, D.A., Mirnics, $K$. Transcriptome alterations in the prefrontal cortex of subjects with schizophrenia who committed suicide. Neuropsychopharmacologia Hungarica. 2008; 10: 9-14.

130. Cowburn, R.F., Marcusson, J.O., Eriksson, A., Wiehager, B., O’Neill, C. Adenylyl cyclase activity and G-protein subunit levels in postmortem frontal cortex of suicide victims. Brain Res. 1994; 633: 297-304.

131. Bunney, W.E., Bunney, B.G, Molecular clock genes in man and lower animals: possible implications for circadian abnormalities in depression. Neuropsychopharmacol.2000; 22: 335-345.

132. Serretti, A., Drago, A., Ronchi,D. HTR2A gene variants and psychiatric disorders: a review of current literature and selection of SNPs for future studies. Curr med chem. 2007; 14: 2053-2069.
133. McMahon, F.J., Buervenich, S., Charney, D., Lipsky, R., Rush, A.J., et al. Variation in the gene encoding the serotonin $2 \mathrm{~A}$ receptor is associated with outcome of antidepressant treatment. Am J Hum Genet.2006; 78: 804-814.

134. Stanley, M., Mann, J.J. Increase serotonin-2 binding sites in frontal cortex of suicide victims. Lancet.1983; 1: 214-216.

135. Turecki, G., Briere, R., Dewar, K., Antonetti, T., Lesage, A.D., et al. Prediction of level of serotonin 2A receptor binding by serotonin receptor $2 \mathrm{~A}$ genetic variation in postmortem brain samples from subjects who did or did not commit suicide. Am J Psychiatry.1999; 156: 1456-1458.

136. Hrdina, P.D., Du, L. Levels of serotonin receptor $2 A$ higher in suicide victims? Am J Psychiatry.2001; 158: 147-148.

137. Pandey, G.N., Dwivedi, Y., Rizavi, H.S., Ren, X., Pandey, S.C., et al. Higher expression of serotonin 5-HT(2A) receptors in the postmortem brains of teenage suicide victims. Am J Psychiatry.2002; 159: 419-429.

138. Shelton, R.C., Sanders-Bush, E., Manier, D.H., Lewis, D.A. Elevated 5-HT2A receptors in postmortem prefrontal cortex in major depression is associated with reduced activity of protein kinase A. Neuroscience. 2009 158: 1406-1415.

139. Stockmeier, C.A., Dilley, G.E., Shapiro, L.A., Overholser, J.C., Thompson, P.A., et al. Serotonin receptors in suicide victims with major depression. Neuropsychopharmacology.1997; 16: 162-173.

140. Gross-Isseroff, R., Salama, D., Israeli, M., Biegon, A. Autoradiographic analysis of $[3 \mathrm{H}]$ ketanserin binding in the human brain postmortem: effect of suicide. Brain Res. 1990; 507: 208-215.

141. Rosel, P., Arranz, B., San, L., Vallejo, J., Crespo, J.M., et al. Altered 5-HT(2A) binding sites and second messenger inositol trisphosphate (IP(3)) levels in hippocampus but not in frontal cortex from depressed suicide victims. Psychiatry Res. 2000; 99: 173-181.

142. Underwood, M.D., Kassir, S.A., Bakalian, M.J., Galfalvy, H., Mann, J.J., et al. Neuron density and serotonin receptor binding in prefrontal cortex in suicide. Int J Neuropsychopharmacol. 2011; 15(4): 435-37.

143. Young, L.T., Li, P.P., Kish, S.J., Siu Po, K., Kamble, A., et al. Cerebral cortex Gsa protein levels and forskolin-stimulated cyclic AMP formation are increased in bipolar affective disorder. J Neurochem.1993; 61: 890-898.

144. Rahman, S., Li. P.P., Young. L.T., Kofman, O., Kish, S.J., et al. Reduced $[3 \mathrm{H}]$ cyclic AMP binding in postmortem brain from subjects with bipolar affective disorder. J Neurochem.1997; 68: 297-304

145. Dowlatshahi, D., MacQueen, G.M., Wang, J.F., Reiach, J.S., Young, L.T. G Protein-coupled cyclic AMP signaling in postmortem brain of subjects with mood disorders: effects of diagnosis, suicide, and treatment at the time of death. J Neurochem.1999; 73: 1121-1126. 
146. Dwivedi, Y., Rao, J.S., Rizavi, H.S., Kotowski, J., Conley, R.R., et al. Abnormal expression and functional characteristics of cyclic adenosine monophosphate response element binding protein in postmortem brain of suicide subjects. Arch Gen Psychiat.2003; 60: 273-282.

147. Wann, B.P., D’Anjou, B., Bah, T.M., Webster, H.H., Godbout, R., et al. Effect of olfactory bulbectomy on adenylyl cyclase activity in the limbic system. Brain Res Bulletin.2009; 79: 3236.

148. Maisonpierre, P.C., Le Beau, M.M., Espinosa 3rd, R., Ip, N.Y., Belluscio, L., de la Monte, S.M., Squinto, S., Furth, ME., Yancopoulos, G.D. Human and rat brain-derived neurotrophic factor and neurotrophin-3: gene structures, distributions, and chro- mosomal localizations. Genomics. 1991; 10 (3): 558568.

149. Webster, M.J., Weickert, C.S., Herman, M.M., Kleinman, J.E. BDNF mRNA expression during postnatal development, maturation and aging of the human prefrontal cortex. Developmental Brain Research.2002; 139 (2): 139-150.

150. Liu, L., Foroud, T., Xuei, X., Berrettini, W., Byerley, W., Coryell, W., El-Mallakh, R., Gershon, E.S., Kelsoe, J.R., Lawson, W.B., MacKinnon, D.F., McInnis, M., McMahon, F.J., Murphy, D.L., Rice, J., Scheftner, W., Zandi, P.P., Lohoff, F.W., Niculescu, A.B., Meyer, E.T., Edenberg, H.J., Nurnberger Jr., J.I. Evidence of association between brain- derived neurotrophic factor gene and bipolar disorder. Psychiatric Genetics. 2008; 18 (6): 267274.

151. Sears, C., Markie, D., Olds, R., Fitches, A. Evidence of associations between bipolar disorder and the brain-derived neurotrophic factor (BDNF) gene. Bipolar Disord. 2011; 13 (78): 630-637.

152. Neves, F.S., Malloy-Diniz, L., Romano-Silva, M.A., Campos, S.B., Miranda, D.M., De Marco, L., Figueira, P.G., Krebs, M.O., Correa, $\mathrm{H}$. The role of BDNF genetic polymorphisms in bipolar disorder with psychiatric comorbidities. Journal of Affective Disord. 2011; 131 (1-3): 307-311.

153. Chen, Z.Y., Jing, D., Bath, K.G., leraci, A., Khan, T., Siao, C.J., Herrera, D.G., Toth, M., Yang, C., McEwen, B.S., Hempstead, B.L., Lee, F.S., Genetic variant BDNF (Val66Met) polymorphism alters anxiety-related behavior. Science. 2006; 314 (5796): 140-143.

154. Schumacher, J., Jamra, R.A., Becker, T., Ohlraun, S., Klopp, N., Binder, E.B., Schulze, T. G., Deschner, M., Schmal, C., Hofels, S., Zobel, A., Illig, T., Propping, P., Holsboer, F., Rietschel, M., Nothen, M.M., Cichon, S., Evidence for a relationship between genetic variants at the brain-derived neurotrophic factor (BDNF) locus and major depression. Biological Psychiatry. 2005; 58 (4): 307-314.

155. Licinio, J., Dong, C., Wong, M.L. Novel sequence variations in the brain- derived neurotrophic factor gene and association with major depression and antidepressant treatment response. Arch Gen Psychiatry. 2009; 66 (5), 488-497.
156. (de) Montigny, C. Cholecystokinin tetrapeptide induces paniclike attacks in healthy volunteers. Preliminary findings. Arch Gen Psychiatry. 1989; 46 (6), 511-517.

157. Dwivedi, Y., Rizavi, H.S., Conley, R.R., Roberts, R.C., Tamminga, C.A., Pandey, G.N., 2003. Altered gene expression of brainderived neurotrophic factor and receptor tyrosine kinase B in postmortem brain of suicide subjects. Arch Gen Psychiatry; 60 (8): 804-815.

158. Kim, B., Kim, C.Y., Hong, J.P., Kim, S.Y., Lee, C., Joo, Y.H. Brain-derived neurotrophic factor Val/Met polymorphism and bipolar disorder. Association of the Met allele with suicidal behavior of bipolar patients. Neuropsychobiology. 2008; 58 (2): 97-103.

159. Kim, Y.-K., Lee, H.-P., Won, S.-D., Park, E.-Y., Lee, H.-Y., Lee, B.-H., Lee, S.-W., Yoon, D., Han, C., Kim, D.-J., Choi, S.-H. Low plasma BDNF is associated with suicidal behavior in major depression. Prog Neuropsychopharmacol Biol Psychiatry. 2007; 31 (1): 78-85.

160. Dwivedi, Y., Mondal, A.C., Rizavi, H.S., Conley, R.R. Suicide brain is associated with decreased expression of neurotrophins. Biological Psychiatry. 2005; 58 (4): 315-324.

161. Kamali, M., Saunders, E.F.H., Prossin, A.R., Brucksch, C.B., Harrington, G.J., Langenecker, S.A., Mclnnis, M.G. Associations between suicide attempts and elevated bedtime salivary cortisol levels in bipolar disorder (2012) Journal of Affective Disorders, 136 (3), pp. 350-358.

162. Meleiros A, Bahls S. O comportamento suicida. In: Maleiros A, Teng CT, Wang YP. Suicídio: Estudos Fundamentais. São Paulo: Segmento Farma; 2004. p. 21-2.

163. World Health Organization. Shaping the future. The World Health Report 2003. Geneva: WHO; 2003.

164. Mann JJ. A current perspective of suicide and attempted suicide. Ann Intern Med. 2002; 136: 302-11.

165. Wang YP, Mello-Santos C, Bertolote JM. Epidemiologia do suicídio. In: Meleiros A, Teng CT, Wang YP. Suicídio: Estudos Fundamentais. São Paulo: Segmento Farma; 2004. p. 104.

166. Grinspoon L. Suicide - part I. The Harvard Medical School. Mental Health Newsletter 1986; 2: 8-16.

167. Botega $N$, Barros $M$, Oliveira $H$, Dalgalarrondo P, Marin-León L. Suicidal behavior in the community: prevalence and factors associated with suicidal ideation. Rev Bras Psiquiatr. 2005; 27(1): 45-53.

168. Nery-Fernandes, F. Miranda-Scippa, A. Suicidal behavior in bipolar affective disorder and socio-demographic, clinical and neuroanatomical characteristics associated. Archives of Clinical Psychiatry. 2013. 40 (6).

169. Isometsä $E$, Henriksson $M$, Marttunen $M$, Heikkinen $M$, Aro $H$, Kuoppasalmi $\mathrm{K}$, et al. Mental disorders in young and middle aged men who commit suicide. BMJ. 1995; 310: 1366-7. 
170. Beautrais $A L$, Joyce $P R$, Mulder RT, Fergusson DM, Deavoll BJ, Nightingale SK. Prevalence and comorbidity of mental disorders in persons making serious suicide attempts: a casecontrol study. Am J Psychiatry. 1996; 153: 1009-14.

171. Goodwin F, Jamison K. Manic-Depressive Illness. 2nd ed. New York: Oxford University Press; 2007. p. 223-69

172. Angst F, Stassen HH, Clayton PJ, Angst J. Mortality of patients with mood disorders: follow-up over 34-38 years. J Affect Disord. 2002; 68: 167-81

173. Harris EC, Barraclough B. Suicide as an outcome for mental disorders: a meta analysis. Br J Psychiatry. 1997; 170: 205-28.

174. Kandel DB, Raveis VH, Davies M. Suicidal ideation in adolescence: Depression, substance use, and other risk factors. J Youth Adolesc. 1991 Apr; 20(2): 289-309.

175. Cassidy, F., 2011. Risk factors of attempted suicide in bipolar disorder. Suicide Life Threat. Behav. 41 (1), 6-11.

176. Bellivier, F., Yon, L., Luquiens, A., et al., 2011. Suicidal attempts in bipolar disorder: results from an observational study (EMBLEM). Bipolar Disord. 13 (4), 377-386.

177. Parmentier, C., Etain, B., Yon, L., et al., 2012. Clinical and dimensional characteristics of euthymic bipolar patients with or without suicidal behavior. Eur. Psychiatry 27 (8), 570-576.

178. Suicidology AAo. 2000. American Association of Suicidology [AAS]. Offical 1998 statistics.

179. Tondo, L., Albert, M.J., Baldessarini, R.J., 2006. Suicide rates in relation to health care access in the United States: an ecological study. J. Clin. Psychiatry 67 (4), 517-523.

180. Costa, LS et al. Risk factors for suicide in bipolar disorder: A systematic review. Journal of Affective Disorders 170 (2015) 237-254.

181. Rihmer, Z. Suicide risk in mood disorders. Curr Opin Psychiatry. 2007. 20: 17-22

182. Marangell LB, Bauer MS, Dennehy EB, et al: Prospective predictors of suicide and suicide attempts in 1,556 patients with bipolar disorders followed for up to 2 years. Bipolar Disord 2006; 8: 566-575.

183. Turecki G, Ernst C, Jollant F, Labonte B \& Mechawar N: The neurodevelopmental origins of suicidal behavior. Trends Neurosci 2012; 35: 14-23.

184. Klara Latalova, Dana Kamaradova \& Jan Prasko: SUICIDE IN BIPOLAR DISORDER: A REVIEW Psychiatria Danubina, 2014; Vol. 26, No. 2, pp 108-114.

185. Manchia M, Hajek T, O'Donovan C, Deiana V, Chillotti C, Ruzickova M, Del ZM \& Alda M: Genetic risk of suicidal behavior in bipolar spectrum disorder: analysis of 737 pedigrees. Bipolar Disord 2013; 15: 496-506.

186. Chang JC, Chen HH, Yen AM, Chen SL \& Lee CS: Survival of bipolar depression, other type of depression and comorbid ailments: ten-year longitudinal follow-up of 10,922 Taiwanese patients with depressive disorders (KCIS no. PSY1). Psychiatr Res 2012; 46: 1442-1448
187. Oquendo MA, Currier D, Liu SM, Hasin DS, Grant BF \& Blanco $C$ : Increased risk for suicidal behavior in comorbid bipolar disorder and alcohol use disorders: results from the National Epidemiologic Survey on Alcohol and Related Conditions (NESARC). Clin Psychiatry 2010; 71: 902-909.

188. Galfavy, H., Oquendo, M.A., Carballo, J.J., et al., 2006. Clinical predictors of suicidal acts after major depression in bipolar disorder: a prospective study. Bipolar Disord. 8 (5 Pt 2), 586595.

189. Valtonen, H.M., Suominen, K., Mantere, O., et al., 2006. Prospective study of risk factors for attempted suicide among patients with bipolar disorder. Bipolar Disord. 8 (5 Pt 2), 576585.

190. Akiskal, H.S., Benazzi, F., Perugi, G., et al., 2005. Agitated "unipolar" depression reconceptualized as a depressive mixed state: Implications for the antidepressant-suicide controversy. J. Affect. Disord. 85 (3), 245-258.

191. Miklowitz, D.J., Chang, K.D., 2008. Prevention of bipolar disorder in at-risk children: theoretical assumptions and empirical foundations. Dev. Psychopathol. 20, 881-897.

192. Algorta, G.P., Youngstrom, E.A., Frazier, T.W., et al., 2011. Suicidality in pediatric bipolar disorder: predictor or outcome of family processes and mixed mood presentation? Bipolar Disord. 13 (1), 76-86.

193. Azorin, J.M., Kaladjian, A., Adida, M., et al., 2009. Risk factors associated with lifetime suicide attempts in bipolar I patients: findings from a French National Cohort. Compr. Psychiatry 50 (2), 115-120

194. Goldstein, T.R., Ha, W., Axelson, D.A., et al., 2012. Predictors of prospectively examined suicide attempts among youth with bipolar disorder. Arch. Gen. Psychiatry 69 (11), 1113-1122.

195. Brent, D.A., Perper, J.A., Moritz, G., et al., 1994. Familial risk factors for adolescent suicide: a case-control study. Acta Psychiatr. Scand. 89 (1), 52-58.

196. Magno, L.A.V., Santana, C.V.N., Rezende, V.B., et al., 2011. Genetic variations in FOXO3A are associated with Bipolar Disorder without confering vulnerability for suicidal behavior. J. Affect. Disord. 133 (3), 633-637.

197. Weissman MM, Klerman GL, Markowitz JS, Ouellette R. Suicidal ideation and suicide attempts in panic disorder and attacks. New England Journal of Medicine.

198. Bostwick JM, Pankratz VS. Affective disorders and suicide risk: a reexamination. American Journal of Psychiatry. 2000; 157: 1925-32.

199. Phillips MR, Yang G, Li S, Li Y. Suicide and the unique prevalence pattern of schizophrenia in mainland China: a retrospective observational study. Lancet. 2004; 364: 1062-8.

200. Nock MK et al. Mental disorders, comorbidity and suicidal behavior: results from the National Comorbidity Survey Replication. Mol Psychiatry. 2010 Aug; 15(8): 868-76.

201. Goodwin FK, Jamison KR (1990): Manic Depressive Illness. New York: Oxford Press, pp 44, 135, 230. 
202. Winokur G, Tsuang M (1975): The lowa 500: Suicide in mania, depression and schizophrenia. Am J Psychiatry 132: 650-651.

203. Chen YW, Dilsaver SC (1995): Comorbidity for panic disorder in bipolar illness: Evidence from the ECA survey. Am J Psychiatry 152: 280-282.

204. Beautrais AL: Risk factors for suicide and attemptedsuicide among young people. Australian and New ZealandJournal of Psychiatry 2000; 34: 420-436.

205. Wasserman D, Rihmer Z, Rujescu D, Sarchiapone M,Sokolowski M, Titelman D, Zalsman G, Zemishlany Z \&Carli V: The European Psychiatric Association (EPA)guidance on suicide treatment and prevention. EurPsychiatry 2012; 27: 129-141.

206. Lam DH \& Wong G: Prodromes, coping strategies andpsychological interventions in bipolar disorders. ClinPsychol Rev 2005; 25: 1028-1042.

207. MiklowitzDJ,OttoMW, FrankE, Reilly-HarringtonNA,Wisniewski SR, Kogan JN, Nierenberg, et al: Psychosocialtreatments for bipolar depression: a 1-year randomizedtrial from the SystematicTreatment EnhancementProgram. Arch Gen Psychiatry 2007; 64: 419-26.

208. Miklowitz DJ \& Taylor DO: Family-focused treatment ofthe suicidal bipolar patient. Bipolar Disord 2006; 8: 640-51

209. Kennedy $\mathrm{N}$ et al. Gender differences in incidence and age at onset of mania and bipolar disorder over a 35-year period in Camberwell, England. Am J Psychiatry. 2005 Feb; 162(2): 25762.

\section{Comment on this article:}

\section{(f) [B] in $8+\mathbf{S}$ P}

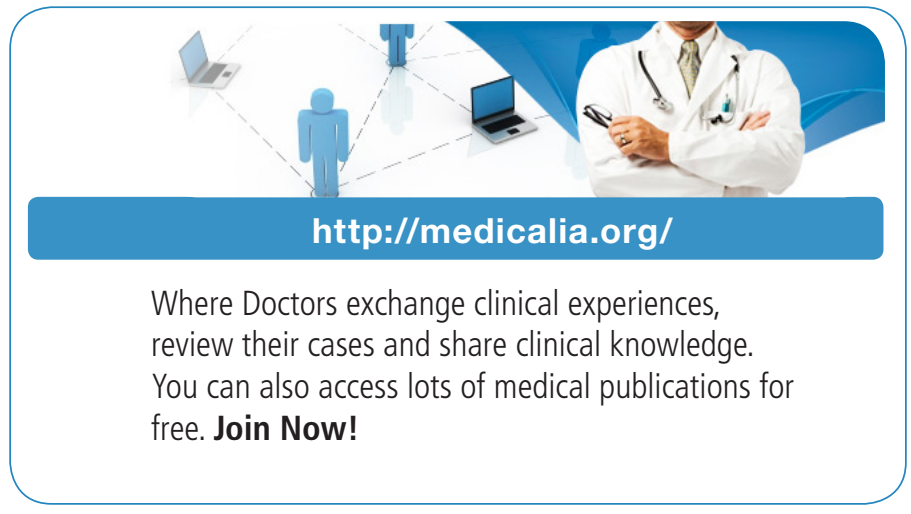

\section{Publish with iMedPub}

http://www.imed.pub

International Archives of Medicine is an open access journal publishing articles encompassing all aspects of medical science and clinical practice. IAM is considered a megajournal with independent sections on all areas of medicine. IAM is a really international journal with authors and board members from all around the world. The journal is widely indexed and classified Q1 in category Medicine. 